\title{
A kinetic model for quantitative evaluation of the effect of hydrogen and osmolarity on hydrogen production by Caldicellulosiruptor saccharolyticus
}

\author{
Mattias Ljunggren ${ }^{1 *}$, Karin Willquist ${ }^{2}$, Guido Zacchi $^{1}$ and Ed WJ van Niel ${ }^{2}$
}

\begin{abstract}
Background: Caldicellulosiruptor saccharolyticus has attracted increased interest as an industrial hydrogen $\left(\mathrm{H}_{2}\right)$ producer. The aim of the present study was to develop a kinetic growth model for this extreme thermophile. The model is based on Monod kinetics supplemented with the inhibitory effects of $\mathrm{H}_{2}$ and osmotic pressure, as well as the liquid-to-gas mass transfer of $\mathrm{H}_{2}$.

Results: Mathematical expressions were developed to enable the simulation of microbial growth, substrate consumption and product formation. The model parameters were determined by fitting them to experimental data. The derived model corresponded well with experimental data from batch fermentations in which the stripping rates and substrate concentrations were varied. The model was used to simulate the inhibition of growth by $\mathrm{H}_{2}$ and solute concentrations, giving a critical dissolved $\mathrm{H}_{2}$ concentration of $2.2 \mathrm{mmol} / \mathrm{L}$ and an osmolarity of 0.27 to $29 \mathrm{~mol} / \mathrm{L}$. The inhibition by $\mathrm{H}_{2}$, being a function of the dissolved $\mathrm{H}_{2}$ concentration, was demonstrated to be mainly dependent on $\mathrm{H}_{2}$ productivity and mass transfer rate. The latter can be improved by increasing the stripping rate, thereby allowing higher $\mathrm{H}_{2}$ productivity. The experimentally determined degree of oversaturation of dissolved $\mathrm{H}_{2}$ was 12 to 34 times the equilibrium concentration and was comparable to the values given by the model.

Conclusions: The derived model is the first mechanistically based model for fermentative $\mathrm{H}_{2}$ production and provides useful information to improve the understanding of the growth behavior of $C$. saccharolyticus. The model can be used to determine optimal operating conditions for $\mathrm{H}_{2}$ production regarding the substrate concentration and the stripping rate.
\end{abstract}

\section{Background}

The question of climate change, together with the increasing scarcity and cost of fossil fuels, has triggered research on the sustainable production of energy carriers, such as biofuels. Although a wide spectrum of alternative fuels and processes are available, it is still not known which of them will succeed in replacing fossil fuels in the long term. Processes for producing some biofuels, such as ethanol and methane, are already highly developed for commercial use, while others, including biohydrogen, require more basic research

\footnotetext{
* Correspondence: mattias.ljunggren@chemeng.lth.se

'Department of Chemical Engineering, Lund University, PO Box 123, SE-221 00 Lund, Sweden

Full list of author information is available at the end of the article
}

before they can be produced in an economically feasible way [1].

The current major drawbacks of fermentative hydrogen $\left(\mathrm{H}_{2}\right)$ production are its low yield [2] and the requirement of gas stripping to remove $\mathrm{H}_{2}$ from the liquid [3]. Dark fermentation can be performed at either moderate or elevated temperatures: the productivity is generally higher in the former case [4], whereas the latter provides higher yields [5]. However, for an economically sustainable biohydrogen process, high productivity should be accompanied by high yields [2]. One solution is to focus on the process design, such as the optimization of $\mathrm{H}_{2}$ removal and substrate concentration [6]. A higher substrate concentration is required to avoid excess amounts of water, since a surplus of process water has a negative effect on both the environmental
C Biomed Central

() 2011 Ljunggren et al; licensee BioMed Central Ltd. This is an Open Access article distributed under the terms of the Creative Commons Attribution License (http://creativecommons.org/licenses/by/2.0), which permits unrestricted use, distribution, and reproduction in any medium, provided the original work is properly cited. 
and economic aspects of the process [7]. It is important to find alternatives to nitrogen $\left(\mathrm{N}_{2}\right)$ sparging, as this dilutes the $\mathrm{H}_{2}$, leading to a lower-grade product or the need for expensive gas upgrading to remove the $\mathrm{N}_{2}$.

The extreme thermophile Caldicellulosiruptor saccharolyticus may be of industrial interest because of its ability to produce high yields of $\mathrm{H}_{2}$ from a wide variety of sugars $[8,9]$, ranging from pentose and hexose monomers [10] to complex (hemi)cellulosic materials $[8,11,12]$. However, the growth of this microorganism, as well as the production of $\mathrm{H}_{2}$ and acetic acid, is subject to substrate and product inhibition [13]. In addition, it is sensitive to increased osmotic pressure [14], making it necessary to dilute the substrate. Moreover, C. saccharolyticus is inhibited by $\mathrm{H}_{2}$ [13], which is a general trait of $\mathrm{H}_{2}$-producing organisms. A high dissolved $\mathrm{H}_{2}$ concentration $\left(\mathrm{H}_{2 \mathrm{aq}}\right)$ inhibits $\mathrm{H}_{2}$-generating hydrogenases $[1,2]$, leading to increased nicotinamide adenine dinucleotide, reduced/nicotinamide adenine dinucleotide (NADH/NAD) ratios, resulting in a metabolic shift toward reduced products such as lactate and ethanol $[1,3,4]$ and thus decreased $\mathrm{H}_{2}$ productivity.

The critical partial $\mathrm{H}_{2}$ pressure $\left(P_{\mathrm{H}_{2}}\right)$ is usually the parameter coupled to growth inhibition and lactate formation [5,13,15-17], although it has been shown that there are mass transfer limitations that cause the fermentation medium to be supersaturated with $\mathrm{H}_{2}$ $[18,19]$. Therefore, $\mathrm{H}_{2 \mathrm{aq}}$ should be considered rather than $P_{\mathrm{H}_{2}}$ when discussing inhibition by $\mathrm{H}_{2}$. Stripping with $\mathrm{N}_{2}$, which decreases $\mathrm{H}_{2 \mathrm{aq}}$ [19], can significantly improve the $\mathrm{H}_{2}$ yield [3]. Indeed, optimizing the process should consist of a compromise between minimizing the stripping gas flow rate, henceforth called the "stripping rate," and maintaining a suitable $\mathrm{H}_{2}$ yield and productivity [20]. However, optimization must take $\mathrm{H}_{2}$ productivity into account, since it influences $\mathrm{H}_{2 \mathrm{aq}}$ greatly; otherwise, the optimization will be relevant only to the specific system studied and cannot be applied to other biohydrogen systems. Furthermore, better insight into $\mathrm{H}_{2}$ productivity and liquid-to-gas mass transfer will help considerably in finding technical solutions allowing an economical and feasible fermentation process to be designed.

This paper describes the development of a kinetic Monod-based model for cell growth and product formation by $C$. saccharolyticus, which takes the liquid-to-gas mass transfer into consideration. The derived model successfully simulates batch fermentations of C. saccharolyticus and predicts the influence of $\mathrm{H}_{2 \mathrm{aq}}$ and osmotic pressure on growth as well as the metabolic shift to lactate production. To the best of our knowledge, this is the first time the inhibitory effects and liquid-to-gas mass transfer of $\mathrm{H}_{2}$ and carbon dioxide $\left(\mathrm{CO}_{2}\right)$ have been included in a model for fermentative $\mathrm{H}_{2}$ production. The results obtained with the model are relevant for biohydrogen systems other than that described herein using C. saccharolyticus.

\section{Methods}

\section{Cultivation and fermentation}

C. saccharolyticus was cultivated in a $\mathrm{N}_{2}$ atmosphere in modified DSM640 medium as described previously [9]. Cultures for inocula were grown overnight in 250-mL serum flasks containing $50 \mathrm{~mL}$ of modified DSM640 medium, together with a $0.4 \%$ carbon source and $0.02 \%$ cysteine.

Fermentations were performed in a jacketed 3-L reactor (Applikon, Schiedam, the Netherlands) at a working volume of $1 \mathrm{~L}$. The $\mathrm{pH}$ was monitored using an ADI 1025 Bio Console Bio Controller (Applikon) and maintained at $\mathrm{pH} 6.6$ (corresponding to neutral $\mathrm{pH}$ at $70^{\circ} \mathrm{C}$ ) by the addition of sodium hydroxide $(\mathrm{NaOH})$. The temperature was thermostatically maintained at $70^{\circ} \mathrm{C} \pm 1{ }^{\circ} \mathrm{C}$, and the stirring rate was set to $350 \mathrm{rpm}$. Prior to inoculation, the medium was reduced by the addition of $0.1 \%$ cysteine. The fermentor was continuously stripped with $\mathrm{N}_{2}$.

A total of eight experiments were performed, with glucose concentrations of 5 or $10 \mathrm{~g} / \mathrm{L}$ and stripping rates from 0.78 to $6 \mathrm{~L}$ of $\mathrm{N}_{2}$ /hour, to estimate the parameters of the kinetic model. The experiments were performed on four different occasions. An overview of the experiments is given in Table 1 . The $\mathrm{H}_{2}$ productivity and the cumulative $\mathrm{H}_{2}$ production were determined as described previously [21].

\section{Measurement of dissolved hydrogen concentration}

The dissolved $\mathrm{H}_{2}$ concentration, $\mathrm{H}_{2 \mathrm{aq}}$, was determined in samples of cell suspensions from the bioreactor in serum flasks. The pressure in the flasks was reduced using a vacuum pump to withdraw the fermentation medium (30 to $40 \mathrm{~mL}$ ) from the fermentor. The sealed flasks were placed in a water bath $\left(20^{\circ} \mathrm{C}\right)$ with magnetic stirring to ensure good mixing. After one hour in the water bath, the pressure in the flasks was rapidly raised

\section{Table 1 Main characteristics of the eight fermentation experiments $^{\mathrm{a}}$}

\begin{tabular}{lcc}
\hline Experiment & Glucose concentration (g/L) & Stripping rate (L/hour) \\
\hline 1 & 5 & 6 \\
2 & 10 & 6 \\
3 & 5 & 6 \\
4 & 5 & 0.78 \\
5 & 5 & 6 \\
6 & 5 & 1.2 \\
7 & 5 & 1.56 \\
8 & 10 & 6 \\
\hline
\end{tabular}

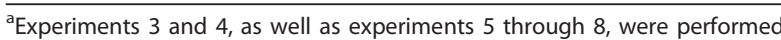
using the inocula from the same preculture, respectively. 
to atmospheric pressure by inserting a small needle through the cap, allowing air to enter the flasks. After 12 hours, the $\mathrm{H}_{2}$ concentration in the headspace of the serum flasks was measured as described below (Analytical methods). The volume of the collected liquid and the total volume of the individual serum flasks were measured to estimate the original $\mathrm{H}_{2 \mathrm{aq}}$ in the sample.

\section{Analytical methods}

Headspace samples were analyzed for $\mathrm{CO}_{2}$ and $\mathrm{H}_{2}$ using a Varian CP-4900 Micro GC gas chromatograph (Varian, Inc., Middelburg, the Netherlands) equipped with a thermal conductivity detector $(100 \mathrm{~mA})$. The results were analyzed using Galaxie Chromatography Workstation version 1.9.3.2 software (Varian, Inc.). The optical density of aerobic samples was measured at $620 \mathrm{~nm}$ using a spectrophotometer (Hitachi U-1100; Hitachi High-Technologies Corp., Tokyo, Japan). Concentrations of acetic acid, lactic acid and ethanol were analyzed using high-pressure liquid chromatography (Waters Corp., Milford, MA, USA). An Aminex HPX-87H ion exchange column (Bio-Rad Laboratories, Hercules, CA, USA) was used at $45^{\circ} \mathrm{C}$ with a mobile phase of $5 \mathrm{mM}$ $\mathrm{H}_{2} \mathrm{SO}_{4}$ at a flow rate of $0.6 \mathrm{~mL} /$ minute. The chromatograph was equipped with a refractive index detector (RID-6A; Shimadzu, Kyoto, Japan).

\section{Modeling}

The model employed in this study considers the kinetics of growth and product formation, including inhibition, liquid-to-gas mass transfer and the chemical equilibrium of $\mathrm{CO}_{2}$ and carbonates. The constants used in the model are listed in Table 2.

\section{Growth and product kinetics in C. saccharolyticus}

The kinetic model for C. saccharolyticus is based on simultaneous solution of the mass balance equations. The following reactions occurring in C. saccharolyticus were taken into consideration in the model:

Table 2 The constants used in the model

\begin{tabular}{lc}
\hline Constant & Values \\
\hline$K_{1}$ & $6.3 \mathrm{~atm}$ \\
$K_{2}$ & $10.3 \mathrm{~L} \mathrm{~atm} / \mathrm{K} / \mathrm{mol}$ \\
$K_{\mathrm{G}}$ & $0.048 \mathrm{mmol} / \mathrm{L}$ \\
$H_{H_{z}}$ & $7.40 \times 10^{-9} \mathrm{~mol} / \mathrm{L} / \mathrm{Pa}$ \\
$H_{C O_{z}}$ & $2.70 \times 10^{-7} \mathrm{~mol} / \mathrm{L} / \mathrm{Pa}$ \\
$\mathrm{pH}$ & $6.6 \mathrm{~L}$ \\
$P_{\text {tot }}$ & $1 \mathrm{~atm}$ \\
$R$ & $0.082 \mathrm{~L} \mathrm{~atm} / \mathrm{K} / \mathrm{mol}$ \\
$r_{\text {cd }}$ & $0.014 / \mathrm{hour}$ \\
$T$ & $70^{\circ} \mathrm{C}$ \\
$V_{\mathrm{g}}$ & $0.05 \mathrm{~L}$ \\
$V_{\mathrm{i}}$ & $1.00 \mathrm{~L}$ \\
\hline
\end{tabular}

$$
\begin{aligned}
& \text { Glucose }+2 \mathrm{H}_{2} \mathrm{O} \rightarrow 2 \mathrm{C}_{2} \mathrm{H}_{4} \mathrm{O}_{2}+2 \mathrm{CO}_{2}+4 \mathrm{H}_{2} \\
& \text { Glucose } \rightarrow 2 \mathrm{C}_{3} \mathrm{H}_{6} \mathrm{O}_{3} \\
& \text { Glucose } \rightarrow k \mathrm{CH}_{1.62} \mathrm{O}_{0.46} \mathrm{~N}_{0.23} \mathrm{~S}_{0.0052} \mathrm{P}_{0.0071}
\end{aligned}
$$

The elemental composition of C. saccharolyticus was previously determined by de Vrije et al. [21]. The value of the stoichiometric parameter $k$ in equation 3 is not known and was therefore estimated (described in detail below, Experimental design and estimation of kinetic parameters). Furthermore, reaction 3 is not balanced, since elements are available in the fermentation medium which were not considered in the model (for example, yeast extract). C. saccharolyticus is subject to several inhibiting agents affecting cell growth as well as the production of acetic acid and $\mathrm{H}_{2}$. These include (1) elevated concentrations of dissolved $\mathrm{H}_{2}$ and $\mathrm{H}_{2 \mathrm{aq}}$, and (2) high osmolarity. Osmolarity (named "OSM" in the model) is calculated by summing the molar can be described by the following expression:

$$
O S M=G+2 \cdot A c+2 \cdot C_{2 s o l}+2 \cdot L a c+0.1
$$

where G, $A c$ and $L a c$ are the concentrations of glucose, acetic acid and lactic acid, respectively, and $\mathrm{CO}_{2 \text { sol }}$ is the concentration of bicarbonate and carbonate, resulting from the $\mathrm{CO}_{2}$ produced by the bacterium. The stoichiometric factor 2 arises from the assumption that for each mole of acid produced, one mole of $\mathrm{NaOH}$ is added to maintain the $\mathrm{pH}$. The background osmolarity, $0.10 \mathrm{~mol} / \mathrm{L}$, resulting from yeast extract and other nutrients was calculated based on osmolarity measurements presented previously [14].

The mass balance for the growth of the cells (in batch fermentation) can be described by the following expression:

$$
\text { Cell mass : } \frac{d X}{d t}=\left(\mu-r_{c d}\right) \cdot X
$$

where $\mu, X$ and $r_{\mathrm{cd}}$ are the specific growth rate, the cell mass concentration and the cell death rate, respectively.

The specific growth rate, $\mu$, is given by Monod kinetics:

$$
\mu=\mu_{\text {max }} \cdot \frac{G}{G+K_{G}} \cdot\left(1-\left(\frac{O S M}{O_{\text {SSM }} \text { crit }}\right)^{n_{\mu}}\right) \cdot\left(1-\left(\frac{H_{2 a q}}{H_{2 a q c r i t}}\right)^{n_{H_{2}}}\right)
$$

Here $\mu_{\max }$ is the maximum specific growth rate, $G$ is the glucose concentration and $K_{\mathrm{G}}$ is the glucose affinity parameter. $O S M_{\text {crit }}, \mathrm{H}_{2 \text { aqcrit }}, n_{H_{2}}$ and $n_{\mu}$ are the critical osmolarity, critical dissolved $\mathrm{H}_{2}$ concentration and the exponential parameters describing the level of inhibition, respectively. The critical parameters represent the values 
at which inhibition is $100 \%$. The kinetic inhibition expressions, as presented by Han and Levenspiel [22], are valid only for concentrations of the inhibiting agents (OSM or $\mathrm{H}_{2 \mathrm{aq}}$ ) lower than the respective critical concentrations. Elevated osmolarity inhibits the growth of C. saccharolyticus [14], which may lead to a metabolic shift toward the production of lactic acid [23].

\section{Product formation}

The product formation rates were expressed using an adapted form of the Luedeking-Piret equation [24]:

$$
\frac{d P_{i}}{d t}=\alpha_{i} \cdot \mu \cdot X+\beta
$$

Here, $\alpha$ is a growth-associated constant, and $\beta$ is a nongrowth-associated constant. All products were assumed to be only growth-associated, hence $\beta$ is zero. This simplification is based on the assumption that other nutrients are in excess. It is further assumed that $\mathrm{H}_{2}$ inhibits its own production and thus also that of acetate in both a direct and an indirect way: indirectly through the inhibition of growth, and directly through specifically inhibiting the hydrogenases, which results in an increase in the NADH/ NAD ratio in the cell [25]. This in turn induces the activity of the enzyme lactate dehydrogenase, initiating a metabolic shift toward lactate [23]. Besides being activated through $\mathrm{H}_{2}$, lactic acid production is also activated via osmolarity, which at high concentrations inhibits growth [23]. The growth-associated constants (equation 7) for the metabolic products are as follows:

$$
\begin{aligned}
& \alpha=R_{A c F} \cdot I N H I B \quad \operatorname{mol~Ac} /(\text { mol cells }) \\
& \alpha_{\mathrm{Lac}}=R_{\mathrm{LacFH}_{2}} \cdot A C T_{\mathrm{H}_{2}}+R_{\mathrm{LacFOSM}} \cdot A C T_{\mathrm{OSM}} \mathrm{mol} \mathrm{Lac} /(\mathrm{mol} \text { cells }) \\
& \alpha_{H_{2}}=\alpha_{A c} \cdot\left(Y_{G_{2}} / Y_{G A c}\right) \quad \mathrm{mol} \mathrm{H}_{2} /(\text { mol cells }) \\
& \alpha_{\mathrm{CO}_{2}}=\alpha_{\mathrm{H}_{2}} \cdot\left(Y_{\mathrm{GCO}_{2}} / Y_{\mathrm{GH}_{2}}\right) \quad \mathrm{mol} \mathrm{CO} /(\text { mol cells })
\end{aligned}
$$

Here $R_{\mathrm{AcF}}, R_{\mathrm{LacFH}_{2}}$ and $\mathrm{R}_{\mathrm{LacFOSM}}$ are the factors relating the production rates of acetic acid and lactic acid to the growth rate; INHIB and ACT are the inhibition and activation factors, respectively (see below, Product formation) $Y_{\mathrm{GAc}}$ and $Y_{\mathrm{GCO}_{2}}$ are the stoichiometric yield coefficients of the reactions described above (equation 1); and $Y_{\mathrm{GH}_{2}}$ is the estimated $\mathrm{H}_{2}$ yield coefficient ( $\mathrm{mol} \mathrm{H}_{2} / \mathrm{mol}$ glucose). The following inhibition mechanisms were studied.

Inhibition and activation by dissolved $\mathrm{H}_{2}$ :

$$
\begin{aligned}
& I N H I B=1-\left(\frac{H_{2 a q}}{H_{2 a q_{c r i t}}}\right)^{n_{\mathrm{H}_{2}}} \\
& \text { ACT }_{\mathrm{H}_{2}}=\left(\frac{H_{2 a q}}{H_{2 a q_{c r i t}}}\right)^{n_{\mathrm{H}_{2}}}
\end{aligned}
$$

Activation of lactic acid production by osmolarity:

$$
A C T_{\text {OSM }}=\left(\frac{O S M}{\text { OSM }_{\text {crit }}}\right)^{n \mu}
$$

The mass balances of the products in the liquid phase consist of an accumulation, time-dependent, and a product formation rate, concentration-dependent, term, and, when applicable, a liquid-to-gas mass transfer term.

Acetic acid: $\quad \frac{d A}{d t}=\alpha_{A c} \cdot \mu \cdot X$

$$
\text { Lactic acid: } \quad \frac{d L a c}{d t}=\alpha_{L a c} \cdot \mu \cdot X
$$

$$
\mathrm{H}_{2}: \quad \frac{d H_{2 a q}}{d t}=\alpha_{H_{2}} \cdot \mu \cdot X-k_{1} a_{H_{2}} \cdot\left(H_{2 a q}-H_{2 a q}^{*}\right)
$$

Here $K_{l} a_{H_{2}}$ is the overall volumetric mass transfer coefficient for $\mathrm{H}_{2}$ and $\mathrm{H}_{2 a q}^{*}$ is the $\mathrm{H}_{2}$ saturation concentration.

$\mathrm{CO}_{2}$ :

$$
\begin{aligned}
\frac{d \mathrm{CO}_{2 a q}}{d t} & =\alpha_{\mathrm{COO}_{2}} \cdot \mu \cdot X-k_{1 a C O_{2}} \cdot\left(\mathrm{CO}_{2 a q}-\mathrm{CO}_{2 a q}^{z}\right)-\mathrm{CO}_{2 a q}\left(\frac{10^{-K_{1}}}{10^{-p H}}+10^{-K_{1}} \cdot \frac{10^{-K_{2}}}{\left(10^{-p H}\right)^{2}}\right) \\
& +\mathrm{CO}_{2001}
\end{aligned}
$$

where $K_{l} a_{C_{2}}$ is the overall volumetric mass transfer coefficient for $\mathrm{CO}_{2} ; \mathrm{CO}_{2 \mathrm{aq}}$ and $\mathrm{CO}_{2 a q}^{*}$ are the concentration of dissolved $\mathrm{CO}_{2}$ and the saturation concentration of $\mathrm{CO}_{2}$, respectively; $K_{1}$ and $K_{2}$ are the dissociation constants; and $\mathrm{CO}_{2 \text { sol }}$ is the total concentration of carbonates. The last two expressions in the $\mathrm{CO}_{2}$ mass balance (equation 18) are related to the reaction of $\mathrm{CO}_{2}$ with water to form carbonates (see Additional file: Liquid-to-gas mass transfer and chemistry of $\mathrm{CO} 2$ _- Theory_experiments_and_results). The expressions $K_{l} a_{H_{2}} \cdot\left(H_{2 a q}-H_{2 a q}^{*}\right)$ and $\mathrm{K}_{l} a_{\mathrm{CO}_{2}} \cdot\left(\mathrm{CO}_{2 a q}-\mathrm{CO}_{2 a q}^{*}\right)$ in equations 17 and 18 describe the liquid-to-gas mass transfer of $\mathrm{H}_{2}$ and $\mathrm{CO}_{2}$, respectively (see Additional file: Liquid-to-gas mass transfer and chemistry of $\mathrm{CO} 2$ _Theory_experiments_and_results).

\section{Substrate consumption}

The mass balance of glucose can be written as follows:

$$
\frac{d G}{d t}=-\left[\left(1 / Y_{G X}\right)+\left(1 / Y_{G A c}\right) \cdot \alpha_{A c}+\left(1 / Y_{G L a c}\right) \cdot \alpha_{L a c}\right] \cdot \mu \cdot X
$$

where $Y_{\mathrm{GX}}$ is the cell mass yield coefficient parameter (which is the model notation of the constant $k$ in equation 3) and $Y_{\mathrm{GAc}}$ and $Y_{\mathrm{GLac}}$ are the stoichiometric yield coefficients ( $\mathrm{mol} / \mathrm{mol}$ substrate) describing the theoretical yields of cell mass, acetic acid and lactic acid, respectively.

\section{Gas phase balances}

The gaseous products are produced in the liquid phase, after which they are transported to the gas phase. The mass balances of the various gaseous compounds 
comprise an accumulation term and a gas-to-liquid mass transfer term as well as an inflow and an outflow.

$$
\begin{aligned}
& \mathrm{H}_{2}: \quad \frac{d \mathrm{H}_{2 G}}{d t}=V_{l} / V_{g} \cdot k_{l} a_{\mathrm{H}_{2}} \cdot\left(\mathrm{H}_{2 a q}-H_{2 a q}^{*}\right)-F_{\text {out } \mathrm{H}_{2}} \cdot \frac{P_{\text {tot }}}{V_{g} \cdot R \cdot T} \\
& \mathrm{CO}_{2}: \quad \frac{d \mathrm{CO}_{2 G}}{d t}=V_{l} / V_{g} \cdot k_{l} a_{\mathrm{CO}_{2}} \cdot\left(\mathrm{CO}_{2 a q}-\mathrm{CO}_{2 a q}^{*}\right)-F_{\text {out } C \mathrm{CO}_{2}} \cdot \frac{P_{\text {tot }}}{V_{g} \cdot R \cdot T} \\
& \mathrm{~N}_{2}: \quad \frac{d \mathrm{~N}_{2}}{d t}=\left(F_{\text {in } \mathrm{N}_{2}}-F_{\text {out }} \mathrm{N}_{2}\right) \cdot \frac{P_{\text {tot }}}{V_{g} \cdot R \cdot T}
\end{aligned}
$$

Here $V_{l}$ and $V_{\mathrm{g}}$ are the liquid and gas volume; $k_{l} a$ is the volumetric mass transfer coefficient for the various compounds; $\mathrm{H}_{2 \mathrm{aq}}$ and $\mathrm{CO}_{2 \mathrm{aq}}$ are the dissolved concentrations of $\mathrm{H}_{2}$ and $\mathrm{CO}_{2} ; \mathrm{H}_{2 a q}^{*}$ and $\mathrm{CO}_{2 a q}^{*}$ are the dissolved concentrations of the compounds at equilibrium; $F_{\text {in } \mathrm{N}_{2}}$ is the flow rate of $\mathrm{N}_{2}$ into the fermentor; and $F_{\text {out }} \mathrm{CO}_{2}, \mathrm{~F}_{\text {out } \mathrm{CO}_{2}}$ and $\mathrm{F}_{\text {out } \mathrm{H}_{2}}$ are the effluent flow rates of $\mathrm{N}_{2}, \mathrm{CO}_{2}$ and $\mathrm{H}_{2}$, respectively.

\section{Other equations used}

The equilibrium between $\mathrm{CO}_{2}$, bicarbonate and carbonate was taken into consideration as follows:

$$
\frac{d \mathrm{CO}_{2 s o l}}{d t}=\mathrm{CO}_{2 a q}\left(\frac{10^{-K_{1}}}{10^{-p H}}+10^{-K_{1}} \cdot \frac{10^{-K_{2}}}{\left(10^{-p H}\right)^{2}}\right)-\mathrm{CO}_{2 s o l}
$$

Since the $\mathrm{pH}$ was controlled during fermentation, it was kept constant at 6.6 in the model. For more details, see Additional file 1: Liquid-to-gas mass transfer and chemistry of $\mathrm{CO} 2$ _Theory_experiments_and_results.

Furthermore, the effect of the stripping rate on the volumetric mass transfer coefficients was determined by using the following equation:

$$
k_{l} a_{i}=k_{l} a_{i 0} \cdot\left(F_{i n N_{2}} / F_{0 i n N_{2}}\right)^{\gamma}
$$

where $k_{l} a_{i 0}$ is the volumetric mass transfer coefficient at a stripping rate of $F_{0 i n N_{2}}, k_{l} a_{i}$ is the volumetric mass transfer coefficient at a stripping rate of $F_{i n N_{2}}$ and $\gamma$ is an experimentally determined exponential coefficient.

\section{Experimental design and estimation of kinetic parameters} The mass transfer parameters $\left(K_{l} a_{\mathrm{H}_{2}}\right.$ and $\left.\mathrm{K}_{l} a_{\mathrm{CO}_{2}}\right)$ and the exponential coefficient $(\gamma)$ were determined before the parameters for the microbial kinetics were estimated. The mass transfer parameters were estimated using a methodology described by Hill [26]. The volumetric mass transfer coefficient for $\mathrm{CO}_{2}, K_{l} a_{\mathrm{CO}_{2}}$, was determined and the volumetric mass transfer coefficient for $\mathrm{H}_{2}\left(K_{l} a_{\mathrm{H}_{2}}\right)$ was calculated using the following relation between $k_{l} a$ values and the diffusion coefficients for the compounds in water [18]:

$$
\frac{k_{l} a_{\mathrm{CO}_{2}}}{k_{l} a_{\mathrm{H}_{2}}}=\left(\frac{D_{\mathrm{CO}_{2}}}{D_{\mathrm{H}_{2}}}\right)^{1 / 2}
$$

Here the diffusion coefficients for $\mathrm{CO}_{2}\left(D_{\mathrm{CO}_{2}}\right)$ and $\mathrm{H}_{2}$ $\left(D_{\mathrm{H}_{2}}\right)$ are $1.98 \times 10^{-5}$ and $4.65 \times 10^{-5} \mathrm{~cm}^{2} /$ second, respectively, according to Pauss et al. [18]. Only the most important results in the estimation of the mass transfer parameters are given here; the detailed results and the methodology can be found in Additional file: Liquid-to-gas mass transfer and chemistry of $\mathrm{CO} 2$ _Theory_experiments_and_results.

To determine the kinetic parameters, fermentations were performed at two substrate concentrations and various stripping rates (Table 1). The kinetic parameters studied and estimated were $Y_{\mathrm{GX}}, Y_{\mathrm{GH}_{2}}, \mu_{\max }, R_{\mathrm{AcF}}$, $R_{\mathrm{LacFH}_{2}}, \mathrm{H}_{2 \mathrm{aqcrit}}, n_{\mathrm{H}_{2}}, R_{\mathrm{LacFOSM}}, O S M_{\text {crit }}$ and $n_{\mu}$. Since the experiments were characterized by different growth rates as well as $\mathrm{H}_{2}$ and biomass yields, all parameters except the three related to osmolarity $\left(R_{\text {LacFOSM }}, O S M_{\text {crit }}\right.$ and $n_{\mu}$ ) were estimated simultaneously for each of the $5 \mathrm{~g} / \mathrm{L}$ experiments (that is, experiments 1 and 3 through 7 ), giving five parameter sets (Table 3). Experiments 6 and 7 were carried out under almost the same conditions with the same inocula and were thus used together to estimate one parameter set. The effect of osmolarity was assumed to be negligible in these experiments (experiments 1 and 3 through 7). The validity of this assumption was checked and is discussed below (Kinetic parameters: inhibition by osmolarity). An average of all parameters except $\mu_{\max }$ was then calculated and used to simulate all six experiments. The parameters related to osmolarity were estimated using the $10 \mathrm{~g} / \mathrm{L}$ experiments (that is, experiments 2 and 8).

Finally, the cell death rate $\left(r_{\mathrm{cd}}\right.$; equation 5), was calculated directly from the experimental data by determining, for each experiment, the slope of the biomass curve as it declined and calculating an average value of the slope based on all experiments. The overall affinity constant $\left(K_{\mathrm{G}}\right.$; equation 6$)$ was taken from the literature on bacteria with the same type of glucose transporter system, that is, the ATP-binding cassette transport system (values are given in Table 2) $[10,27,28]$.

The parameters in the model were estimated using a nonlinear least squares method which minimizes the objective function:

$$
L S Q=\sum_{i=c o m p o n e n t}\left[\sum_{t=t i m e}\left(Y_{\text {exp }, i, t}-Y_{\text {model }, i, t}\right)^{2}\right]
$$

where LSQ is the least squares quadratic, that is, the sum of the squared residuals, $Y_{\text {exp }, i, t}$ and $Y_{\text {model }, i, t}$, are the experimental and model values, respectively, at time $t$ for each compound $i$, that is, glucose, acetic acid, lactic acid, cell mass and $\mathrm{H}_{2}$. The parameter estimations were carried out and the 95\% confidence intervals were calculated using the MATLAB functions nlinfit and nlparci, respectively (MathWorks, Natick, MA, USA). 
Table 3 The estimated model parameters for $5 \mathrm{~g}$ of glucose/L experimentsa

\begin{tabular}{|c|c|c|c|c|c|c|c|c|c|c|}
\hline \multirow[b]{3}{*}{ Parameter } & \multicolumn{10}{|c|}{ Experiments } \\
\hline & \multicolumn{2}{|c|}{1} & \multicolumn{2}{|c|}{3} & \multicolumn{2}{|c|}{4} & \multicolumn{2}{|c|}{5} & \multicolumn{2}{|c|}{6 and 7} \\
\hline & Value & $95 \%( \pm)$ & Value & $95 \% \mathrm{Cl}( \pm)$ & Value & $95 \% \mathrm{Cl}( \pm)$ & Value & $95 \% \mathrm{Cl}( \pm)$ & Value & $95 \% \mathrm{Cl}( \pm)$ \\
\hline$\overline{Y_{G H_{z}}}$ & 6.0 & 0.2 & 5.1 & 0.2 & 3.6 & 0.1 & 4.5 & 0.1 & 4.71 & 0.13 \\
\hline$Y_{G X}$ & 2.8 & 0.5 & 6.5 & 1.3 & 5.1 & 0.9 & 4.3 & 0.6 & 5.22 & 0.60 \\
\hline$\mu_{\max }$ & 0.240 & $9 \times 10^{-3}$ & 0.36 & $1.6 \times 10^{-2}$ & 0.33 & $5.6 \times 10^{-2}$ & 0.2 & $2 \times 10^{-4}$ & 0.21 & $4.0 \times 10^{-3}$ \\
\hline$R_{\text {AcF }}$ & 1.4 & 0.2 & 2.0 & 0.2 & 2.3 & 0.4 & 1.8 & $2 \times 10^{-2}$ & 2.0 & $8 \times 10^{-2}$ \\
\hline$R_{\text {LacF }}$ & 0.36 & $7 \times 10^{-2}$ & 0.11 & $9 \times 10^{-2}$ & 0.37 & $9 \times 10^{-2}$ & $9 \times 10^{-2}$ & 0.22 & 0.17 & $5 \times 10^{-3}$ \\
\hline $\mathrm{H}_{\text {2aqcrit }}$ & $1.9 \times 10^{-3}$ & $4 \times 10^{-4}$ & $1.8 \times 10^{-3}$ & $3 \times 10^{-4}$ & $2.3 \times 10^{-3}$ & $7 \times 10^{-4}$ & $1.3 \times 10^{-3}$ & $2 \times 10^{-4}$ & $2.7 \times 10^{-3}$ & $5 \times 10^{-4}$ \\
\hline$n_{H_{z}}$ & 10.7 & 5.6 & 3.1 & 0.6 & 3.3 & 0.8 & 5.2 & 1.7 & 2.9 & 0.3 \\
\hline
\end{tabular}

${ }^{a}$ We assumed that osmolarity did not have an effect at this low concentration. The validity of the assumption was checked and discussed in the Kinetic parameters: inhibition by osmolarity section of text. The value of the parameter and the $95 \%$ confidence interval $(95 \% \mathrm{Cl})$ are given for each parameter.

\section{Results and Discussion}

The order in which the parameters are estimated is important. Since the mass transfer influences fermentation, and thus the corresponding kinetic parameters, the mass transfer parameters were estimated prior to determining the fermentation-related kinetic parameters.

\section{Estimation of the volumetric mass transfer coefficient}

The estimated overall volumetric mass transfer coefficients for $\mathrm{CO}_{2}\left(K_{1} a_{\mathrm{CO}_{2}}\right)$ in the fermentation medium were in the range of 3.4 to 7.2 /hour for stripping rates ranging from 2.0 to $9.8 \mathrm{~L} /$ hour (33 to $164 \mathrm{~mL} /$ minute). The $K_{1} a_{\mathrm{CO}_{2}}$ values obtained with their respective stripping rates were used to calculate the exponential parameter $\gamma$ (equation 24), giving a value of $0.46 \pm 0.02$, which agrees well with previous findings [20,29]. On the basis of the mass transfer results of $\mathrm{CO}_{2}$ and equation $25 K_{l} a_{H_{2}}$ was determined to be $9.0 \pm 0.1$ /hour at a stripping rate of $6 \mathrm{~L} /$ hour $(100 \mathrm{~mL} /$ minute). This value is consistent with previous results for similar systems with stripping rates between 5 and 2,000 $\mathrm{mL} /$ minute, where the $k_{l} a$ values were in the range of 1 to 120 /hour $[18,20]$. Hence, the expression calculating $\mathrm{K}_{l} a_{\mathrm{H}_{2}}$ (equation 24) is:

$$
k_{l} a_{H_{2}}=9.0 \cdot\left(F_{\text {in } N_{2}} / 6.0\right)^{0.46}
$$

where $F_{i n N_{2}}$ is the stripping rate. For more detailed results on mass transfer, see Additional file: Liquid-to-gas mass transfer and chemistry of $\mathrm{CO} 2$ _Theory_experiments_and_results.

\section{Fermentation}

In fermentation experiments 1 through 7, the glucose was completely consumed and acetic acid, $\mathrm{H}_{2}$ and lactic acid were the main products (Figures 1, 2, 3, 4, 5, 6 and 7). In experiment 8 , complete glucose consumption was not achieved within 40 hours (Figure 8).
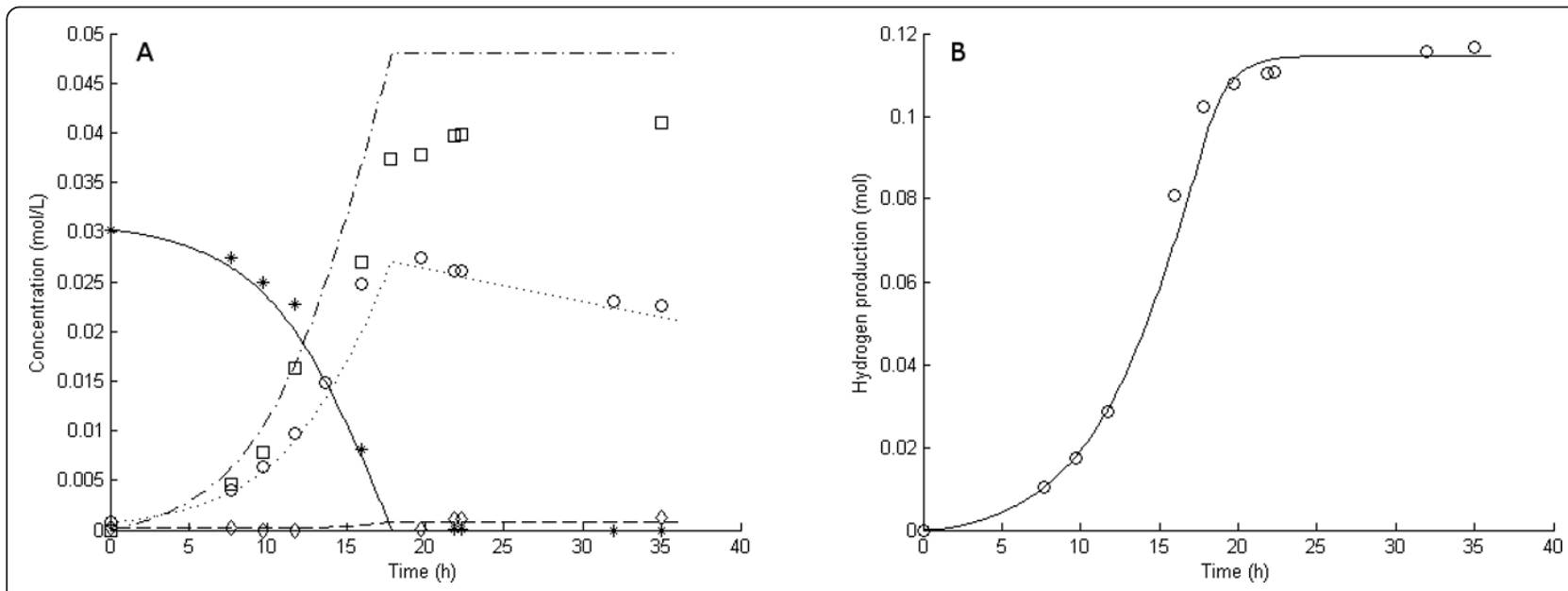

Figure 1 Experimental and model results for experiment 1. Experimental results: (A) Liquid concentrations: Glucose (asterisks), acetic acid (open squares), cell mass (open circles), lactic acid (open diamonds). (B) Accumulated hydrogen $\left(\mathrm{H}_{2}\right)$ production (open circles). Model results: Average values were used for all parameters except $\mu_{\max }$. (A) Liquid concentrations: Glucose (solid lines), acetic acid (dashed-dotted lines), cell mass (dotted lines), lactic acid (dashed lines). (B) Accumulated $\mathrm{H}_{2}$ production (straight lines). 

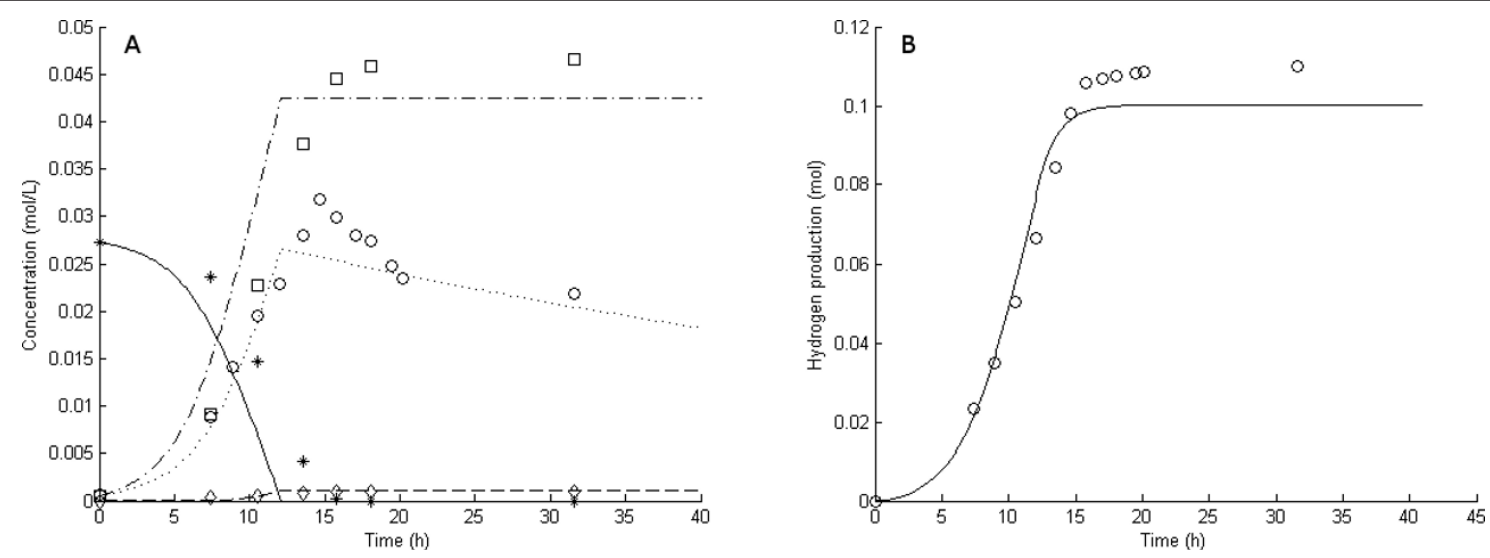

Figure 2 Experimental and model results for experiment 3. Experimental results: (A) Liquid concentrations: Glucose (asterisks), acetic acid (open squares), cell mass (open circles), lactic acid (open diamonds). (B) Accumulated $\mathrm{H}_{2}$ production (open circles). Model results: Average values were used for all parameters except $\mu_{\max }$. (A) Liquid concentrations: Glucose (solid lines), acetic acid (dashed-dotted lines), cell mass (dotted lines), lactic acid (dashed lines). (B) Accumulated $\mathrm{H}_{2}$ production (straight lines).
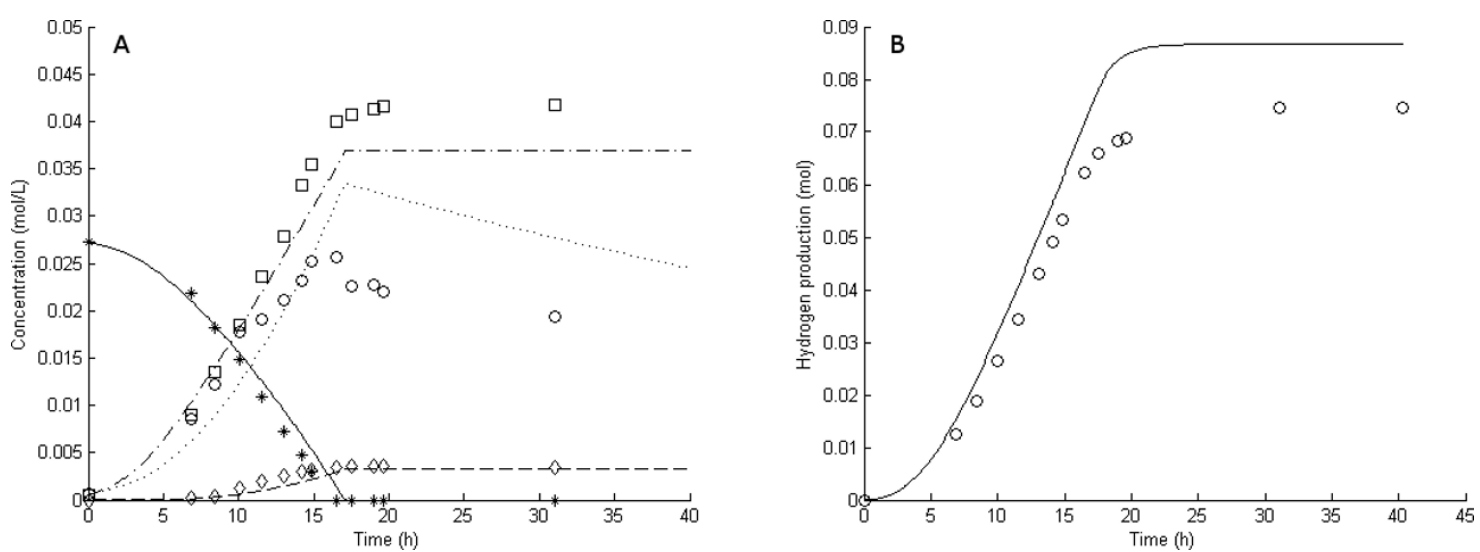

Figure 3 Experimental and model results for experiment 4. Experimental results: (A) Liquid concentrations: Glucose (asterisks), acetic acid (open squares), cell mass (open circles), lactic acid (open diamonds). (B) Accumulated $\mathrm{H}_{2}$ production (open circles). Model results: Average values were used for all parameters except $\mu_{\max }$. (A) Liquid concentrations: Glucose (solid lines), acetic acid (dashed-dotted lines), cell mass (dotted lines), lactic acid (dashed lines). (B) Accumulated $\mathrm{H}_{2}$ production (straight lines).
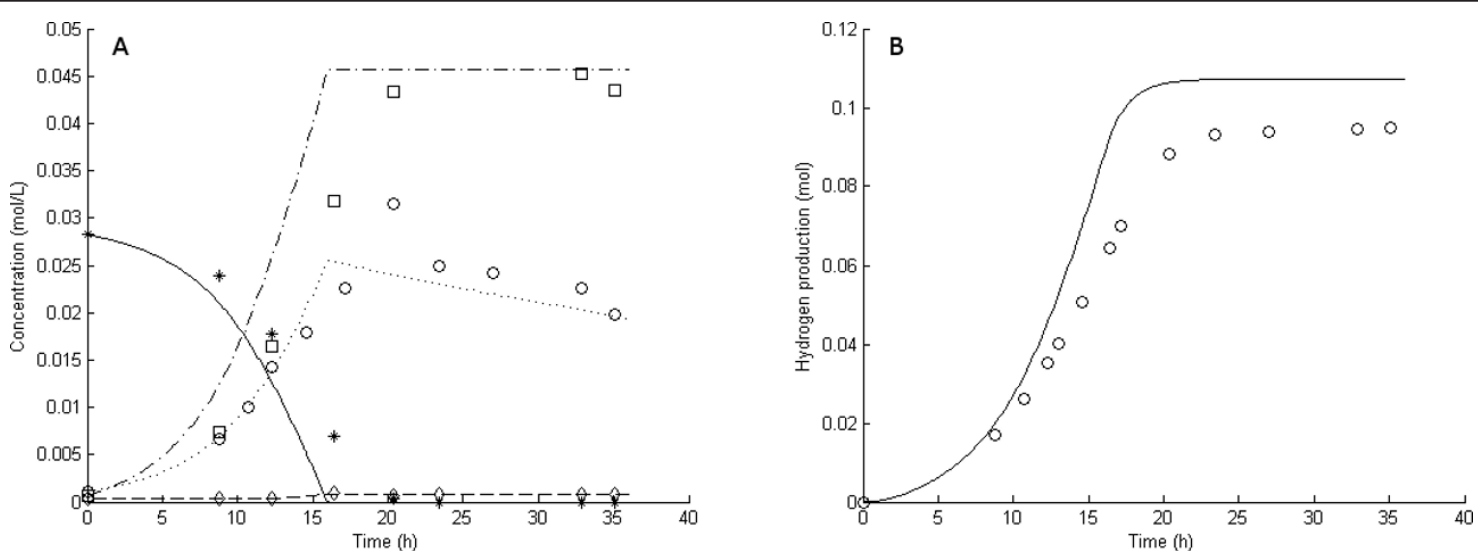

Figure 4 Experimental and model results for experiment 5. Experimental results: (A) Liquid concentrations: Glucose (asterisks), acetic acid (open squares), cell mass (open circles), lactic acid (open diamonds). (B) Accumulated $\mathrm{H}_{2}$ production (open circles). Model results: Average values were used for all parameters except $\mu_{\max }$ (A) Liquid concentrations: Glucose (solid lines), acetic acid (dashed-dotted lines), cell mass (dotted lines), lactic acid (dashed lines). (B) Accumulated $\mathrm{H}_{2}$ production (straight lines). 

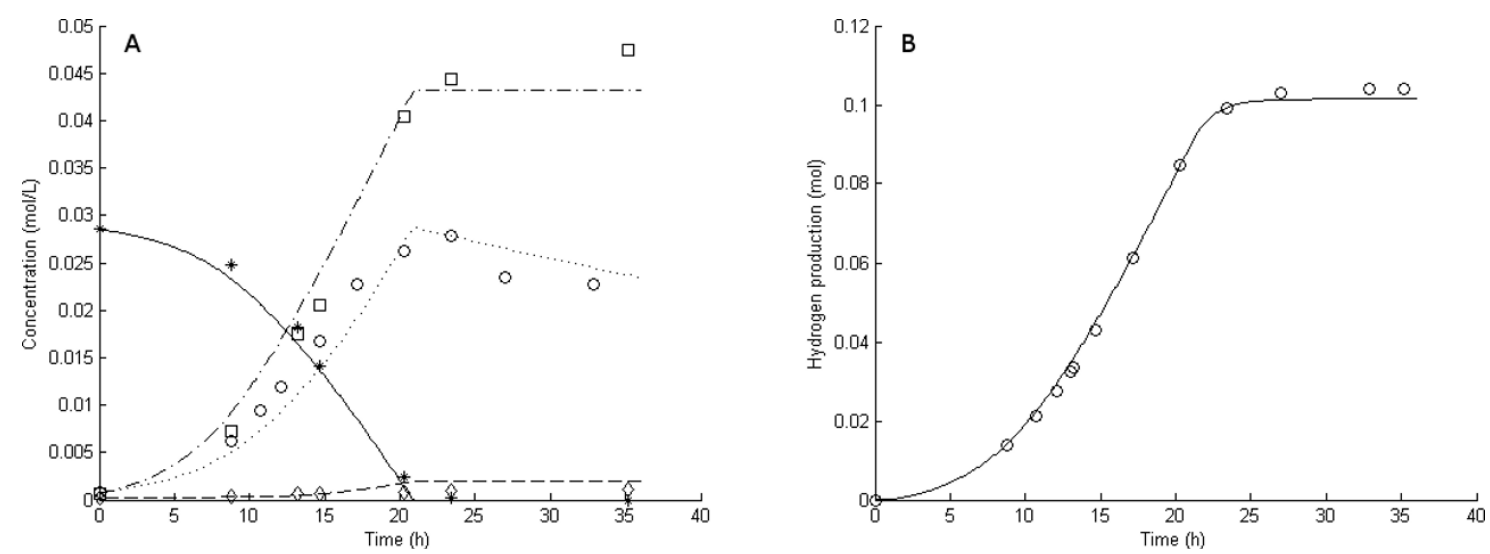

Figure 5 Experimental and model results for experiment 6. Experimental results: (A) Liquid concentrations: Glucose (asterisks), acetic acid (open squares), cell mass (open circles), lactic acid (open diamonds). (B) Accumulated $\mathrm{H}_{2}$ production (open circles). Model results: Average values were used for all parameters except $\mu_{\max }$. (A) Liquid concentrations: Glucose (solid lines), acetic acid (dashed-dotted lines), cell mass (dotted lines), lactic acid (dashed lines). (B) Accumulated $\mathrm{H}_{2}$ production (straight lines).
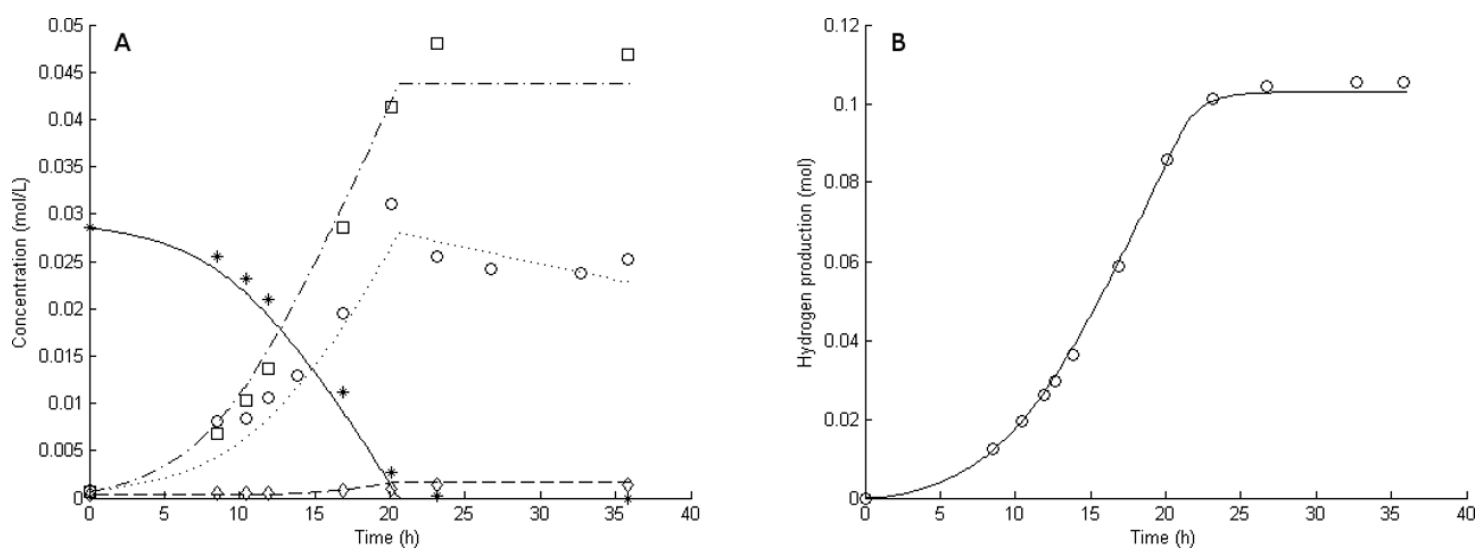

Figure 6 Experimental and model results for experiment 7. Experimental results: (A) Liquid concentrations: Glucose (asterisks), acetic acid (open squares), cell mass (open circles), lactic acid (open diamonds). (B) Accumulated $\mathrm{H}_{2}$ production (open circles). Model results: Average values were used for all parameters except $\mu_{\max }$. (A) Liquid concentrations: Glucose (solid lines), acetic acid (dashed-dotted lines), cell mass (dotted lines), lactic acid (dashed lines). (B) Accumulated $\mathrm{H}_{2}$ production (straight lines).
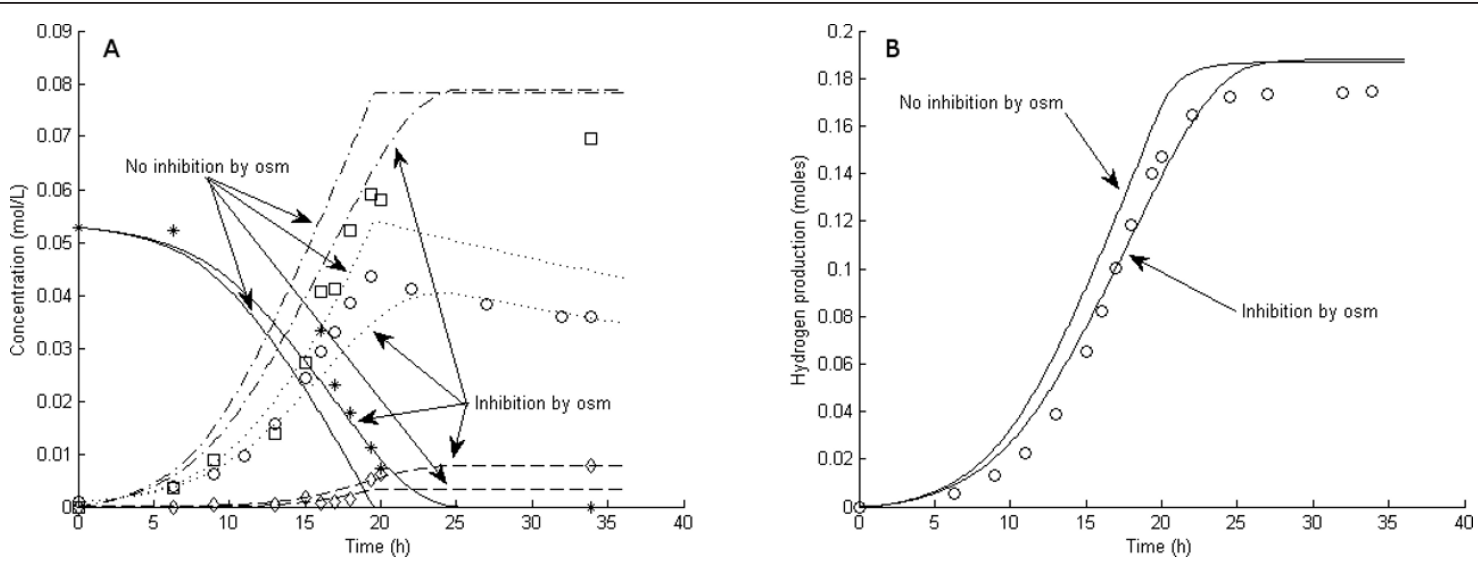

Figure 7 Experimental and model results for experiment 2. Experimental results: (A) Liquid concentrations: Glucose (asterisks), acetic acid (open squares), cell mass (open circles), lactic acid (open diamonds). (B) Accumulated $\mathrm{H}_{2}$ production (open circles). Model results: Average values were used for all parameters except $\mu_{\max }$. For $\mu_{\max }$ a value of $0.25 /$ hour was used. (A) Liquid concentrations: Glucose (solid lines), acetic acid (dashed-dotted lines), cell mass (dotted lines), lactic acid (dashed lines). (B) Accumulated $\mathrm{H}_{2}$ production (straight lines). 

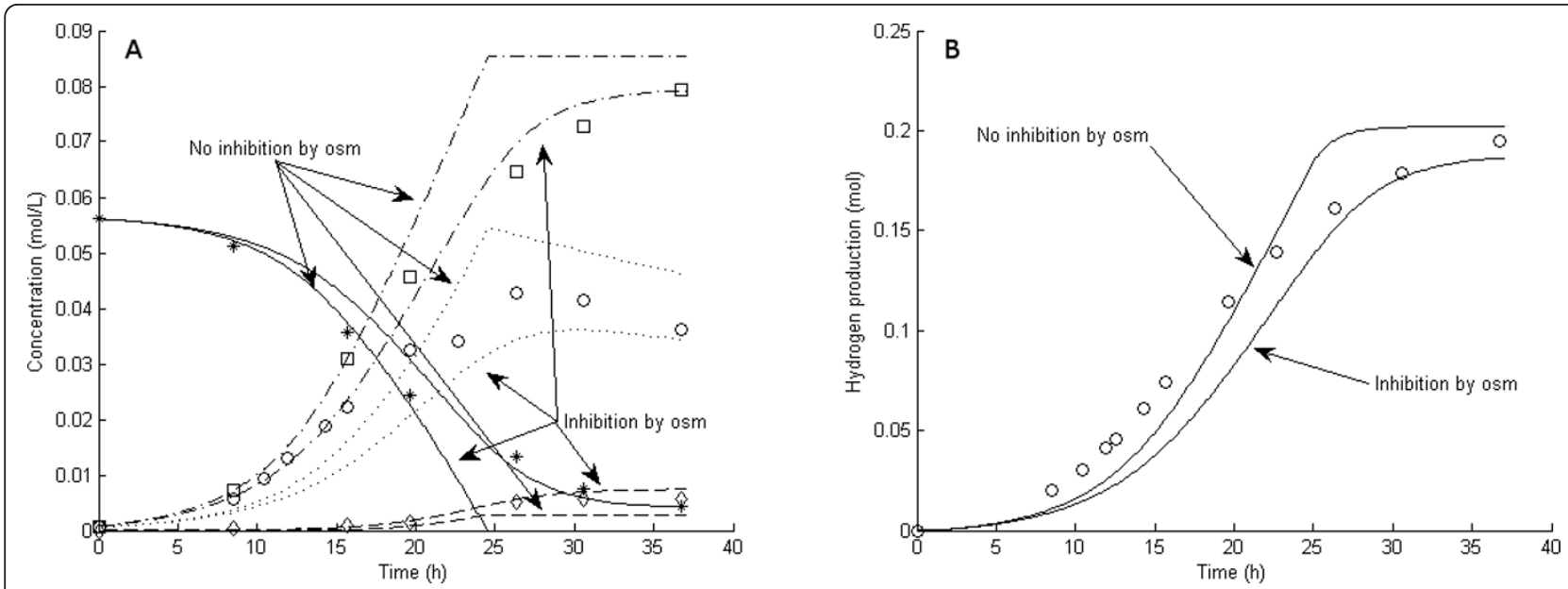

Figure 8 Experimental and model results for experiment 8. Experimental results: (A) Liquid concentrations: Glucose (asterisks), acetic acid (open squares), cell mass (open circles), lactic acid (open diamonds). (B) Accumulated $\mathrm{H}_{2}$ production (open circles). Model results: Average values were used for all parameters except $\mu_{\max }$. For $\mu_{\max }$ the average growth rate of experiment 5 through 7 was used (0.22/hour). (A) Liquid concentrations: Glucose (solid lines), acetic acid (dashed-dotted lines), cell mass (dotted lines), lactic acid (dashed lines). (B) Accumulated $\mathrm{H}_{2}$ production (straight lines).

The six $5 \mathrm{~g} / \mathrm{L}$ experiments (that is, experiments 1 and 3 through 7) differed with respect to growth rate and $\mathrm{H}_{2}$ yield (Figures 1, 2, 3, 4, 5 and 6). The reason for the variations is not clear. However, the two sets of experiments, carried out in parallel using inocula from the same preculture (experiments 3 and 4 as well as experiments 5 through 8 ), showed a strong resemblance. Batch experiments are generally characterized by poor reproducibility, as has also been observed with Escherichia coli [30]. Owing to the variations between the experiments, each of the $5 \mathrm{~g} / \mathrm{L}$ experiments was used separately to estimate all parameters except $O S M_{\text {crit }}, n_{\mu}$ and $R_{\text {LacFOSM }}$, which were estimated using the $10 \mathrm{~g} / \mathrm{L}$ experiments (experiments 2 and 8 and Figures 7 and 8). In addition, acetic acid and $\mathrm{H}_{2}$ were not produced at a stoichiometric ratio (1:2) in any of the experiments, which is in agreement with prior observations in continuous culture $[15,21]$ where the $\mathrm{H}_{2}$ /acetic acid ratio depended on the dilution rate. Instead, less acetate was produced in relation to $\mathrm{H}_{2}$, and the $\mathrm{H}_{2}$ yield was thus considered a parameter in the model. A possible explanation of the nonstoichiometric yield is that acetic acid is used as a building block by the cells.

\section{Growth rates}

The estimated maximum growth rate of $C$. saccharolyticus varied between the different experiments; however, the values were similar for experiments carried out in parallel (that is, experiments 3 and 4 and 5 through 8 ) (Table 3 ). The $\mu_{\max }$ determined for glucose ranged from 0.21 to 0.36 /hour and corresponded well with earlier findings, which varied from 0.2 to $0.5 /$ hour $[14,21]$. Vrije et al. [21] found different values of $\mu_{\max }$ obtained in washout experiments with $C$. saccharolyticus, depending on the growth history of the culture. The reason for the variation in growth rates has not yet been elucidated, but the quality of the inocula used seems to depend on its growth history. The variation in growth rate was considered in the present model by not using an average value of $\mu_{\max }$, while average values were used for all the other parameters (described in more detail below, Kinteic parameters: inhibition by dissolved hydrogen).

Together with changes in the product yields, the variations in growth rates strongly suggest that an as yet unknown factor influences the metabolism. Also, it is likely that the highest value of $\mu_{\max }$ determined in this study $(0.36 /$ hour $)$ is not the true maximum, that is to say, the real $\mu_{\max }$ that can be achieved for glucose by this organism. This could mean that the growth of C. saccharolyticus is normally suppressed, as has been observed for E. coli [30]. The cause of the suppression of the growth of $C$. saccharolyticus is not understood and must be further studied to gain a better understanding of the physiology of the microorganism and to improve the model [21].

\section{Kinetic parameters: inhibition by dissolved hydrogen}

As described above (Growth and product kinetics in C. saccharolyticus), the effects of two environmental conditions, that is to say, $\mathrm{H}_{2 \mathrm{aq}}$ and osmolarity, on the growth, the production of acetic acid and $\mathrm{H}_{2}$, and the activation of lactic acid production of $C$. saccharolyticus were studied. All parameters except and $R_{\text {LacFOSM }}, O S M_{\text {crit }}$ and $n_{\mu}$ were estimated for each of the experiments with $5 \mathrm{~g} / \mathrm{L}$ glucose 
(Table 3), from which their average values were calculated (Table 4). The experimental results are presented in Figures 1, 2, 3, 4, 5, and 6, together with the predictions of the model using the average values of the parameters (except for $\mu_{\max }$ ). The average value of $\mu_{\max }$ was not used because of the large variation in this parameter; instead, the average within each set of parallel experiments was used. The model then agreed well with the experimental results and also reflected the effect of $\mathrm{H}_{2 \mathrm{aq}}$ on the microorganism. Interestingly, the parameter $n_{H_{2}}$ has quite a high value (4.5), which indicates a steplike response to the inhibiting agent, $\mathrm{H}_{2}$; that is, at lower concentrations, the inhibition increases only a little with the concentration, whereas at higher concentrations the inhibition increases dramatically with increased concentration. The value of the $\mathrm{H}_{2}$ yield coefficient parameter, $Y_{\mathrm{GH}_{2}}$, ranged from 3.7 to $6.2 \mathrm{~mol} \mathrm{H}_{2} / \mathrm{mol}$ glucose. The upper value exceeds the Thauer limit, which is $4 \mathrm{~mol} \mathrm{H}_{2} / \mathrm{mol}$ glucose [31]. However, the observed $\mathrm{H}_{2}$ yield obtained in the simulations and in the experiments never exceeded the Thauer limit; that is, the molar ratio of $\mathrm{H}_{2}$ produced to glucose consumed is always below 4 . The high values of $Y_{\mathrm{GH}_{2}}$ are an effect of the nonstoichiometric ratio between $\mathrm{H}_{2}$ and acetic acid seen during the experiments, described as $Y_{\mathrm{GH}_{2}} / Y_{\mathrm{GAc}}$ in the model (equation 10). The ratios are often above $2 \mathrm{~mol} \mathrm{H}_{2} / \mathrm{mol}$ acetic acid and, in the model, this comes out as a higher $\mathrm{H}_{2}$ yield coefficient parameter. The reason for the $\mathrm{H}_{2}$ and acetic acid ratio not being equal to 2 , as the stoichiometry of reaction 1 shows, might be that some of the acetic acid produced is taken up and utilized by the cell.

\section{Dissolved hydrogen: degree of supersaturation and its effect}

Supersaturation of dissolved $\mathrm{H}_{2}$ occurred during fermentation, as measured experimentally and predicted by the model (Table 5), as reported previously $[18,19]$. Oversaturation ranged from 4.9 to 52 times the saturation concentration, which corresponds well with the results of other studies $[18,19]$. The large deviation in the measured values of $\mathrm{H}_{2 \mathrm{aq}}$ (Table 5) is an effect of the

\begin{tabular}{|c|c|c|c|}
\hline Parameter & Mean & Minimum & Maximum \\
\hline$\overline{Y_{G H_{z}}}$ & $4.77 \mathrm{~mol} / \mathrm{mol}$ & $3.46 \mathrm{~mol} / \mathrm{mol}$ & $6.19 \mathrm{~mol} / \mathrm{mol}$ \\
\hline$Y_{G X}$ & $4.78 \mathrm{~mol} / \mathrm{mol}$ & $2.30 \mathrm{~mol} / \mathrm{mol}$ & $7.76 \mathrm{~mol} / \mathrm{mol}$ \\
\hline$\mu_{\max }$ & $0.28 /$ hour & $0.21 /$ hour & $0.51 /$ hour \\
\hline$R_{A C F}$ & 1.91 hour/hour & 1.24 hour/hour & 3.40 hour/hour \\
\hline$R_{\text {LACF }}$ & 0.20 hour/hour & 0.13 hour/hour & 0.43 hour/hour \\
\hline$H_{2 a q c r i t}$ & $2.2 \times 10^{-3} \mathrm{~mol} / \mathrm{L}$ & $9.6 \times 10^{-4} \mathrm{~mol} / \mathrm{L}$ & $4.1 \times 10^{-3} \mathrm{~mol} / \mathrm{L}$ \\
\hline$n_{H_{z}}$ & 4.50 & 0.84 & 16.24 \\
\hline
\end{tabular}

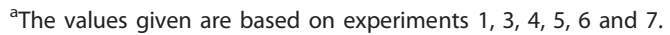

large uncertainties in the measurements. The oversaturation of $\mathrm{H}_{2 \text { aq }}$ can also be clearly seen in Figure 9, where values of $\mathrm{H}_{2 \mathrm{aq}}$ calculated with the model for a few experiments are shown together with the saturation concentration of $\mathrm{H}_{2}$ for experiment 6 .

The experiment with the lowest stripping rate (experiment 4) showed the highest production of lactic acid (Figure 3). The other two experiments with low stripping rates (experiments 6 and 7) (Figures 5 and 6) showed only a slight increase in lactic acid production compared to the experiments with high stripping rates (experiments 1, 3 and 5) (Figures 1, 2 and 4) and very little lactic acid production compared to experiment 4 . This can be explained by the lower growth rates resulting in lower $\mathrm{H}_{2}$ productivity, and hence lower values of $\mathrm{H}_{2 \mathrm{aq}}$, in experiments 5 through 7 (Figures 4, 5 and 6). Experiments 3 and 4 both showed high initial growth rates characterized by a high value of $\mu_{\max }$ and hence high $\mathrm{H}_{2}$ productivity, leading to higher values of $\mathrm{H}_{2 \mathrm{aq}}$. In experiment 4 , with a low stripping rate $(0.78 \mathrm{~L} /$ hour $), \mathrm{H}_{2 \mathrm{aq}}$ reached a plateau faster than it did in the other experiments (Figure 9). At that stage, the culture reached maximum $\mathrm{H}_{2}$ productivity (data not shown), which resulted in linear rates of glucose consumption and $\mathrm{H}_{2}$ and acetic acid production (Figure 4). This behavior was reflected by the model (Figure 4) and can be explained by growth inhibition by $\mathrm{H}_{2}$. When $\mathrm{H}_{2}$ productivity reaches a critical value in the fermentation system, the cells respond with a reduction in the specific growth rate, and hence a plateau is observed. This plateau was reached much faster in experiment 4 than in the other two low-stripping-rate experiments (experiments 6 and 7), which was due to a combination of the higher initial growth rate and $\mathrm{H}_{2}$ productivity and the lower stripping rate (Table 1).

The model with estimated parameters for inhibition by $\mathrm{H}_{2 \text { aq }}$ can be used to indicate how $\mathrm{H}_{2}$ productivity, $P_{H_{2}}$, $\mathrm{H}_{2 \mathrm{aq}}$ and the overall mass transfer coefficient are related (Figure 10). The dissolved $\mathrm{H}_{2}$ concentration in experiment 4 reached almost $80 \%$ of the value of $\mathrm{H}_{2 \text { aqcrit }}$ (indicated by the red line in Figure 10) after 10 hours, and, Dissolved hydrogen: degree of supersaturation and its effect), $\mathrm{H}_{2}$ productivity and hence $\mathrm{H}_{2 \mathrm{aq}}$ were constant until glucose was depleted (Figures 3 and 9). The dissolved $\mathrm{H}_{2}$ concentration in experiment 5 , on the other hand, was always well above the red line in Figure 10 and also showed little lactic acid production. In experiments 6 and $7, \mathrm{H}_{2 \mathrm{aq}}$ also ended up near the red line (Figure 10); however, both reached it much later (at 17 hours; that is, only 4 hours before the glucose was depleted). This was due to lower growth rates and slightly higher stripping rates. Finally, $\mathrm{H}_{2 \mathrm{aq}}$ in experiment 1 crossed the red line after 16 hours with little production of lactic acid, which may be due to an exponential increase in $\mathrm{H}_{2}$ productivity, and the line was crossed when very little glucose 
Table 5 The measured dissolved hydrogen concentration under different fermentation conditions compared with the model $^{\mathrm{a}}$

\begin{tabular}{lcccc}
\hline Experiment & $\mathbf{5}$ & $\mathbf{6}$ & $\mathbf{7}$ & $\mathbf{8}$ \\
\hline $\mathrm{H}_{2}$ concentration & $3.0 \%$ & $9.1 \%$ & $7.5 \%$ & $3.6 \%$ \\
$\mathrm{H}_{2}$ productivity & $8.4 \mathrm{mmol} / \mathrm{L} / \mathrm{hour}$ & $6.0 \mathrm{mmol} / \mathrm{L} / \mathrm{hour}$ & $6.2 \mathrm{mmol} / \mathrm{L} / \mathrm{hour}$ & $10.7 \mathrm{mmol} / \mathrm{L} / \mathrm{hour}$ \\
$\mathrm{H}_{\text {2aq }}$ & $0.28 \pm 0.01 \mathrm{mmol} / \mathrm{L}$ & $0.8 \pm 0.5 \mathrm{mmol} / \mathrm{L}$ & $0.34 \pm 0.02 \mathrm{mmol} / \mathrm{L}$ & $0.9 \pm 0.5 \mathrm{mmol} / \mathrm{L}$ \\
$\mathrm{H}_{\text {2aq }}$ at equilibrium & $0.022 \mathrm{mmol} / \mathrm{L}$ & $0.069 \mathrm{mmol} / \mathrm{L}$ & $0.056 \mathrm{mmol} / \mathrm{L}$ & $0.027 \mathrm{mmol} / \mathrm{L}$ \\
Oversaturation & $12.5 \pm 0.3$ & $12 \pm 7$ & $12.5 \pm 0.4$ & $34 \pm 19$ \\
$\mathrm{H}_{\text {2aq }}$ (model) & $0.96 \mathrm{mmol} / \mathrm{L}$ & $1.50 \mathrm{mmol} / \mathrm{L}$ & $1.36 \mathrm{mmol} / \mathrm{L}$ & $1.22 \mathrm{mmol} / \mathrm{L}$ \\
\hline
\end{tabular}

a Hydrogen $\left(\mathrm{H}_{2}\right)$ concentration, $\mathrm{H}_{2}$ productivity and $\mathrm{H}_{2 \text { aq }}$ are the experimentally determined $\mathrm{H}_{2}$ concentration in the gas phase, $\mathrm{H}_{2}$ productivity and dissolved $\mathrm{H}_{2}$ concentration, respectively. $\mathrm{H}_{2 a q}$ at equilibrium is the corresponding theoretical $\mathrm{H}_{2 a q}$ at equilibrium with the gas. Oversaturation is the experimentally determined degree of $\mathrm{H}_{2}$ oversaturation in the liquid. $\mathrm{H}_{2 a q}$ (model) is the dissolved $\mathrm{H}_{2}$ concentration calculated by the model under the same conditions.

remained; hence almost no substrate was left for lactic acid production (Figure 1).

The organism thus seems to respond to an increase in $\mathrm{H}_{2 \mathrm{aq}}$ by adjusting its growth rate and directing its metabolism toward the production of lactate, thus fine-tuning $\mathrm{H}_{2}$ productivity to prevent $\mathrm{H}_{2 \mathrm{aq}}$ values detrimental to the cell. On the basis of both the experimental data and the model, it is clear that dissolved $\mathrm{H}_{2}$ has a negative effect on $C$. saccharolyticus and that $\mathrm{H}_{2}$ productivity and the stripping rate have a considerable impact on $\mathrm{H}_{2 \mathrm{aq}}$. This can explain why fermentation with high $\mathrm{H}_{2}$ productivity commonly results in low $\mathrm{H}_{2}$ yields $[15,21,32,33]$ and why an increase in the stripping rate tends to increase $\mathrm{H}_{2}$ yield and productivity [20].

Predicting the effect of dissolved hydrogen concentration The dissolved $\mathrm{H}_{2}$ concentration can be lowered by stripping with $\mathrm{N}_{2}$ gas (Figure 11), which also results in

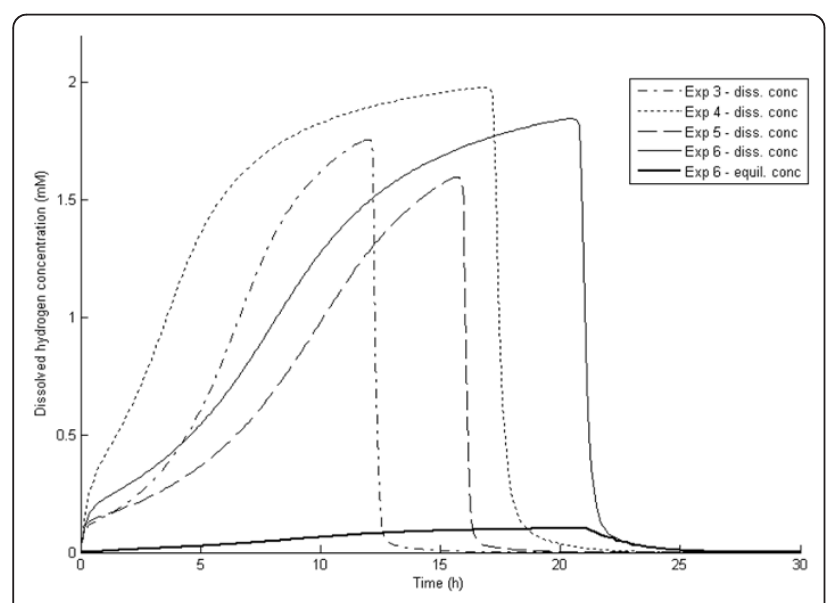

Figure 9 Dissolved hydrogen concentration as a function of fermentation time. The dissolved $\mathrm{H}_{2}$ concentration predicted by the model as a function of fermentation time for experiments 3,4 , 5 and 6 is shown. Note the rapid increase in dissolved $\mathrm{H}_{2}$ concentration in experiment 4 , which is the effect of the low stripping rate and high growth rate. The predicted equilibrium dissolved $\mathrm{H}_{2}$ concentration (based on the partial pressure of $\mathrm{H}_{2}$ ) is also included for experiment 6 . higher $\mathrm{H}_{2}$ yields [19,34-36]. Kraemer and Bagley [20] published details of a study in which they optimized the stripping rate with respect to $\mathrm{H}_{2}$ yield and productivity. They concluded that a stripping rate of $12 \mathrm{~mL} / \mathrm{minute}$, resulting in a volumetric mass transfer rate of $5 /$ hour, was optimal. However, this was only valid for their particular system and not for systems with higher $\mathrm{H}_{2}$ productivity and different liquid-to-gas mass transfer properties. Figure 11 shows $\mathrm{H}_{2 \mathrm{aq}}$ calculated by our model at various stripping rates and $\mathrm{H}_{2}$ productivities for the reactor system used herein. It is evident that $\mathrm{H}_{2 \mathrm{aq}}$ is a function of both variables.

Furthermore, the current model cannot simulate a system without sparging, since $k_{l} a$ is based on the stripping rate (equation 24). However, Figure 10 provides an excellent basis for further discussions, since the relation between $K_{l} a_{\mathrm{H}_{2}}, P_{\mathrm{H}_{2}}$ and $\mathrm{H}_{2}$ productivity still holds, even without stripping. For instance, with $C$. saccharolyticus at a total pressure of $1 \mathrm{~atm}$, no stripping, a productivity of $10 \mathrm{mmol} \mathrm{H}_{2} / \mathrm{L} /$ hour, and a gas composition of $60 \%$ $\mathrm{H}_{2}$ and $40 \% \mathrm{CO}_{2}$, a value of $K_{l} a_{\mathrm{H}_{2}}$ of at least 7.5/hour is required to avoid serious $\mathrm{H}_{2}$ inhibition (Figure 10).

\section{Kinetic parameters: inhibition by osmolarity}

Experiments 2 and 8 were carried out with almost identical initial conditions, but they progressed quite differently, probably due mainly to different inocula and a slight difference in the initial glucose concentration. It was evident that $\mathrm{H}_{2 \mathrm{aq}}$ as the sole inhibitor could not adequately describe the system at elevated substrate concentrations (Figures 7 and 8). Indeed, the model fitted the data from experiments 2 and 8 very well after introducing growth inhibition by osmotic pressure.

The average value of $\mu_{\max }$ in experiments 5 through 7 , which were carried out using the same inocula as experiment 8 , was used for experiment 8 . However, since no experiments were carried out using the same inocula as experiment 2 , together with a low glucose concentration, the value of $\mu_{\max }$ for experiment 2 is not known. Instead, the average value of $\mu_{\max }$ for the three sets of $5 \mathrm{~g} / \mathrm{L}$ experiments (experiment 1, experiments 3 and 4 , and 


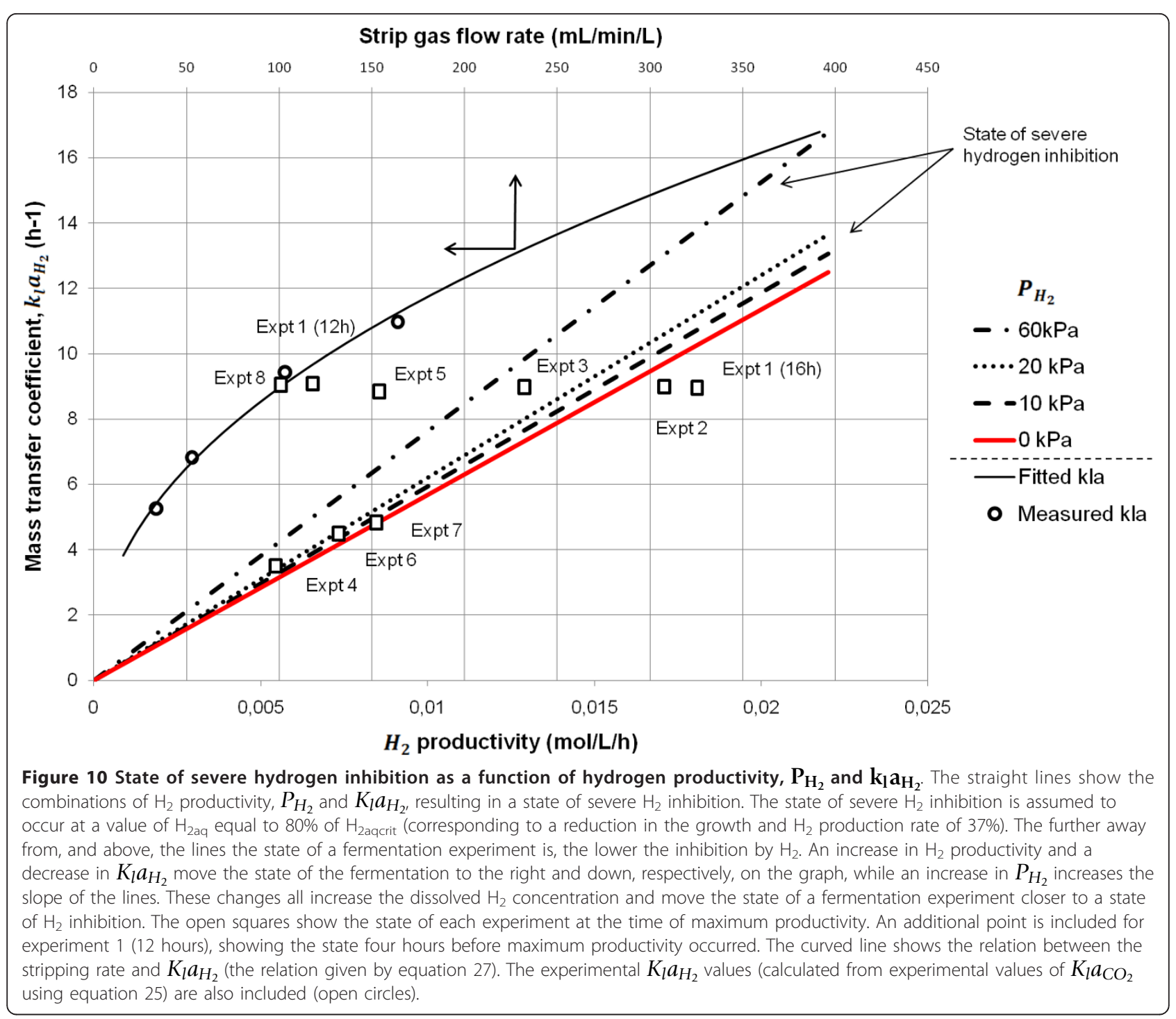

experiments 5 through 7$)$ was assumed ( $0.27 /$ hour $)$ when estimating the inhibition parameters for osmolarity, that is, $R_{\text {LacFOSM }}, O S M_{\text {crit }}$ and $n_{\mu}$ (Table 6). Applying this extended model to the experiments with lower glucose concentrations confirmed that the osmolarity had a minor influence on the outcomes of the fermentations under those conditions. To estimate the three parameters describing the inhibition by osmolarity, $\mu_{\max }$ for experiment 2 had to be assumed. This assumption mainly affects the value of the exponential factor, $n_{\mu}$, and not $R_{\text {LacFOSM }}$ or $O S M_{\text {crit }}$ (Table 5). This strongly indicates that $O S M_{\text {crit }}$ for C. saccharolyticus is in the range of 0.27 to $0.29 \mathrm{~mol} / \mathrm{L}$, a range that is in agreement with previous results of a study by Willquist et al. [14].

Although this rather simple model describes the effect of osmolarity well, some aspects of it cannot be reproduced by this type of unstructured, mechanistic model.
It is evident from Figure 8 that the growth rate, and hence the glucose consumption and acetic acid production rates, are not affected at the initiation of growth, since the model excluding inhibition by osmolarity fits the first three points perfectly. However, at an osmolarity of about $0.2 \mathrm{~mol} / \mathrm{L}$, there is a shift toward a reduction in the growth rate, glucose consumption, and acetic acid production rate, as well as an increase in lactic acid production, rapidly at first, followed by a slow decline of all of them. It is not possible to model this effect, that is, a rapid shift followed by a slow gradual decrease, using a simple inhibition expression. One could assume a very high exponential factor, but that would predict only the beginning of the experiment; however, as inhibition came into effect, the decrease in the growth rate to zero would not be slow and gradual, but very considerable and rapid. 


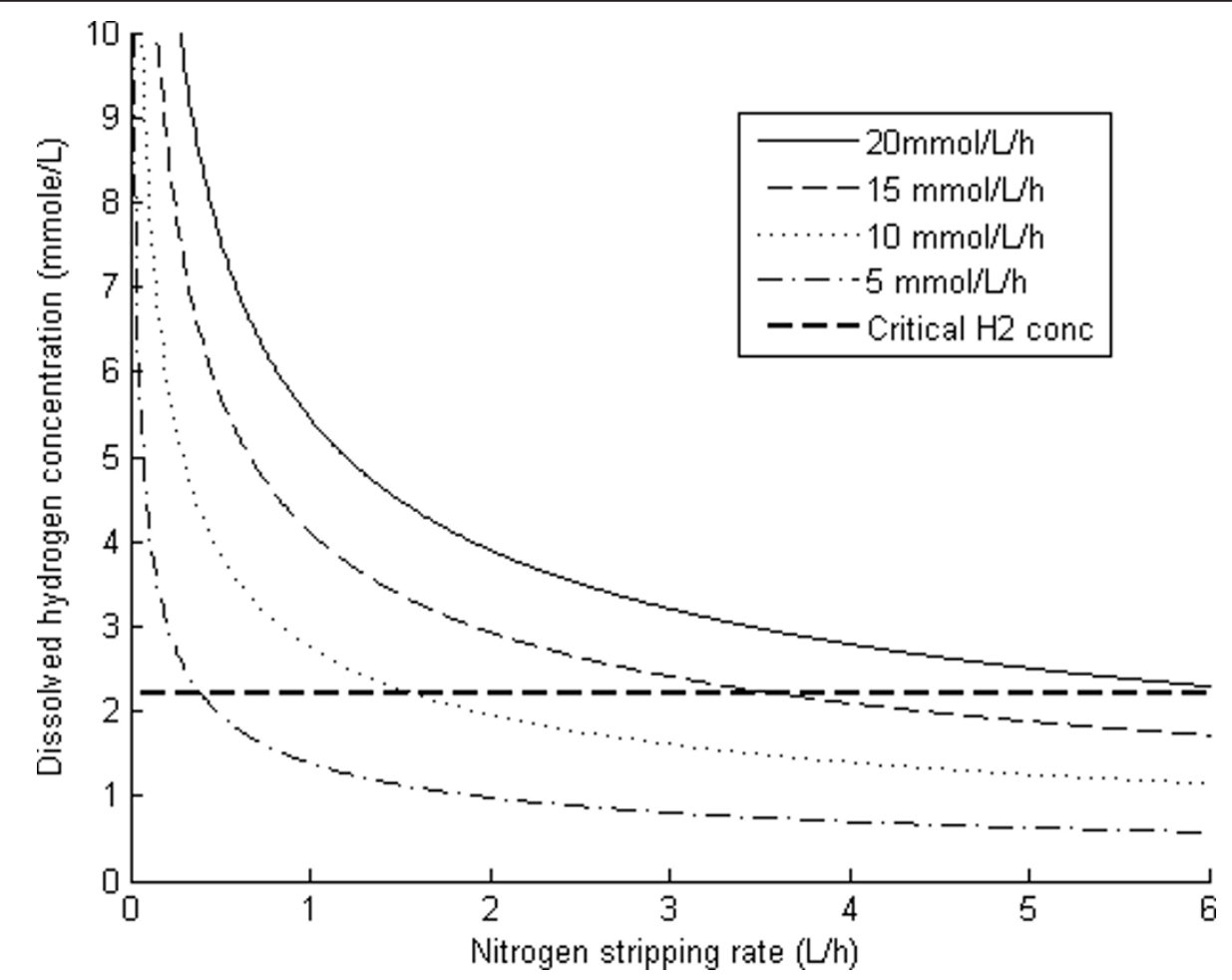

Figure $11 \mathrm{H}_{2 a q}$ as a function of the stripping rate and hydrogen productivity. The horizontal line shows the estimated critical $\mathrm{H}_{2}$ concentration.

\section{Conclusions}

Batch fermentations of C. saccharolyticus on glucose were successfully simulated using Monod kinetics extended to include liquid-to-gas mass transfer and inhibition by $\mathrm{H}_{2 \mathrm{aq}}$ and osmolarity. In agreement with previous measurements $[18,19]$, the model predicted high oversaturation of $\mathrm{H}_{2}$ in the liquid, which was also confirmed experimentally.

To the best of our knowledge, we have demonstrated for the first time the possibility of predicting $\mathrm{H}_{2 \mathrm{aq}}$ and its effect on the fermentation in a laboratory-scale bioreactor as a function of stripping rate and productivity using the derived model. With this tool, it was possible to conclude that the inhibition of growth and $\mathrm{H}_{2}$ production depend on both $\mathrm{H}_{2 \mathrm{aq}}$ and osmolarity. The model described the inhibition by both $\mathrm{H}_{2 \mathrm{aq}}$ and osmolarity satisfactorily and can hence be used to predict the optimal stripping rate

Table 6 The effect of the assumption of $\mu_{\max }$ for experiment 2 on the estimates of the parameters associated with osmolarity ${ }^{\text {a }}$

\begin{tabular}{llll}
\hline Experiment $\mathbf{2} \boldsymbol{\mu}_{\max }$ & $\mathbf{0 . 2 7 / h o u r}$ & $\mathbf{0 . 2 4} /$ hour & $\mathbf{0 . 3 0 / h o u r ~}$ \\
\hline$R_{\text {LacFOSM }}$ & $0.41(0.22)$ & $0.54(0.32)$ & $0.34(0.25)$ \\
OSM $_{\text {Crit }}$ & $0.28(0.01)$ & $0.27(0.01)$ & $0.29(0.01)$ \\
$n_{\mu}$ & $4.68(0.75)$ & $8.73(2.23)$ & $3.61(0.67)$ \\
\hline
\end{tabular}

${ }^{\mathrm{a}}$ Data are values of the parameter with the confidence interval $(\mathrm{Cl}, 95 \%)$ are given for each parameter. and substrate concentration. It also shows how C. saccharolyticus responds to increased osmolarity and $\mathrm{H}_{2 \mathrm{aq}}$. In addition, the modeled relationship between mass transfer, $\mathrm{H}_{2}$ productivity and $\mathrm{H}_{2 \mathrm{aq}}$ is not specific to $C$. saccharolyticus, but can also be applied to other systems. To widen the applicability of the model even further, future studies should aim at incorporating the effect of the stirrer speed and the absence of stripping on the liquid-to-gas mass transfer.

\section{Nomenclature}

Ac: acetic acid concentration $(\mathrm{mol} / \mathrm{L}) ; \mathrm{CO}_{2 \mathrm{aq}}: \mathrm{CO}_{2}$ concentration in the liquid phase $(\mathrm{mol} / \mathrm{L}) ; \mathrm{CO}_{2 a q}^{*}$ : saturation concentration $(\mathrm{mol} / \mathrm{L}) ; \mathrm{CO}_{2 s o}$ : solubilized $\mathrm{CO}_{2}(\mathrm{~mol} / \mathrm{L})$; $\mathrm{F}_{\text {out } \mathrm{CO}_{2}}$ : flow rate of $\mathrm{CO}_{2}$ out of the fermentor (L/hour); $F_{\text {out } \mathrm{H}_{2}}$ : flow rate of $\mathrm{H}_{2}$ out of the fermentor (L/hour); $F_{\text {in } \mathrm{N}_{2}}$ : flow rate of $\mathrm{N}_{2}$ into the fermentor (L/hour); $F_{\text {out } \mathrm{N}_{2}}$ : flow rate of $\mathrm{N}_{2}$ out of the fermentor (L/hour); G: substrate concentration ( $\mathrm{mol} / \mathrm{L}) ; \mathrm{H}_{2 \mathrm{aq}}: \mathrm{H}_{2}$ concentration in the liquid phase (mol/L); $\mathrm{H}_{2 \text { aqcrit }}$ : critical $\mathrm{H}_{2}$ concentration in the liquid phase $(\mathrm{mol} / \mathrm{L}) ; H_{2 a q}^{*}$ : saturation concentration (mol/L); $H_{\mathrm{H}_{2}}$ : Henry's constant for $\mathrm{H}_{2}(\mathrm{~L}$ atm $/ \mathrm{mol}) ; \mathrm{H}_{\mathrm{CO}_{2}}$ : Henry's constant for $\mathrm{CO}_{2}(\mathrm{~L}$ atm $/ \mathrm{mol}) ; K_{1}$ : dissociation constant for $\mathrm{CO}_{2}$ into bicarbonate; $\mathrm{K}_{2}$ : dissociation constant for bicarbonate into carbonate; $K_{1} a_{H_{2}}$ : mass transfer coefficient for $\mathrm{H}_{2}$ (per hour); $K_{1} a_{\mathrm{CO}_{2}}$ : mass transfer 
coefficient for $\mathrm{CO}_{2}$ (per hour); $K_{\mathrm{G}}$ : saturation constant $(\mathrm{mol} / \mathrm{L})$; Lac: lactic acid concentration $(\mathrm{mol} / \mathrm{L}) ; n_{\mu}$ : inhibition coefficient for inhibition by osmolarity; $n_{H_{2}}$ : inhibition coefficient for inhibition by $\mathrm{H}_{2}$; OSM: osmolarity parameter $(\mathrm{mol} / \mathrm{L}) ; O S M_{\text {crit }}$ : critical osmolarity parameter (mol/L); $P_{\mathrm{H}_{2}}:$ partial pressure of $\mathrm{H}_{2}(\mathrm{~Pa}) ; p_{\mathrm{H}_{2}}$ crit: critical partial pressure of $\mathrm{H}_{2}(\mathrm{~Pa})$; $P_{\text {tot }}$ : total pressure (Pa); PPi: pyrophosphate; LSQ: least squares quadratic; $R$ : gas constant $(\mathrm{L} \mathrm{atm} / \mathrm{K} / \mathrm{mol}) ; R_{\mathrm{AcF}}$ : maximum Ac production rate (mol/g cell mass/hour); $R_{\mathrm{LacFH}_{2}}$ : maximum Lac production rate caused by $\mathrm{H}_{2}$ (mol/g cell mass/hour); $R_{\text {LacFOSM: maxi- }}$ mum Lac production rate caused by osmotic pressure (mol/g cell mass/hour); $r_{\mathrm{cd}}$ : death rate of cells (per hour); $T$ : temperature (Kelvin); $V_{\mathrm{g}}$ : gas volume in liquid (L); $V_{\mathrm{l}}$ : liquid volume in reactor $(\mathrm{L}) ; X$ : cell mass concentration $(\mathrm{mol} / \mathrm{L}) ; Y_{\mathrm{GAc}}:$ stoichiometric acetic acid yield (mol acetic acid/mol substrate); $Y_{\mathrm{GCO}_{2}}$ : stoichiometric $\mathrm{CO}_{2}$ yield (mol $\mathrm{CO}_{2} /$ mol substrate); $Y_{\mathrm{GH}_{2}}$ : stoichiometric $\mathrm{H}_{2}$ yield (mol $\mathrm{H}_{2} /$ mol substrate); $Y_{\text {GLac }}$ : stoichiometric lactic acid yield (mol lactic acid/mol substrate); $Y_{\mathrm{GX}}$ : biomass yield (mol cell mass/mol substrate); $\alpha$ : cell-growth-associated constant; $\alpha_{\text {Ac: }}$ cell-growth-associated constant for Ac production rate ( $\mathrm{mol} \mathrm{Ac} / \mathrm{mol}$ cells); $\alpha_{\mathrm{CO}_{2}}$ : cell growth-associated constant for $\mathrm{CO}_{2}$ production rate $\left(\mathrm{mol} \mathrm{CO} \mathrm{CO}_{2} / \mathrm{mol}\right.$ cells); $\alpha_{H_{2}}$ : cell growth-associated constant for $\mathrm{H}_{2}$ production rate ( $\mathrm{mol} \mathrm{H} \mathrm{H}_{2} / \mathrm{mol}$ cells); $\alpha_{\text {Lac }}$ : cell-growth-associated constant for Lac production rate (mol Lac/mol cells); $\beta$ : noncell-growth-associated constant; $\gamma$ : exponential coefficient for mass transfer correlation; $\mu$ : specific growth rate (per hour); $\mu_{\max }$ : maximum specific growth rate (per hour).

\section{Additional material}

Additional file 1: Liquid-to-gas mass transfer and chemistry of CO2_Theory_experiments_and_results. This file contains information on the estimation of the mass transfer parameters as well as the set-up of the mass transfer experiments. The file also contains more detailed information concerning the theory behind the chemistry of carbon dioxide and liquid-to-gas mass transfer.

\section{Acknowledgements}

The authors gratefully acknowledge the Commission of the European Communities, Sixth Framework Programme, Priority 6, Sustainable Energy Systems (019825 HYVOLUTION), as well as the Swedish Energy Agency for their financial support.

\section{Author details}

'Department of Chemical Engineering, Lund University, PO Box 123, SE-221 00 Lund, Sweden. ${ }^{2}$ Department of Applied Microbiology, Lund University, PO Box 124, SE-221 00 Lund, Sweden.

\section{Authors' contributions}

ML developed the model, carried out the parameter estimations and planned as well as performed the mass transfer experiments. ML also wrote the main part of the manuscript and took part in the planning and execution of the fermentation experiments. KW took part in the development of the model, planned and carried out the main part of the fermentation experiments, analyzed the results and assisted in the mass transfer experiments. KW also wrote parts of the manuscript. GZ and EVN participated in the coordination of the study and reviewed the manuscript. All authors read and approved the final manuscript.

\section{Competing interests}

The authors declare that they have no competing interests.

Received: 21 January 2011 Accepted: 13 September 2011 Published: 13 September 2011

\section{References}

1. Hallenbeck PC, Benemann JR: Biological hydrogen production: fundamentals and limiting processes. Int J Hydrogen Energy 2002, 27:1185-1193.

2. Hallenbeck PC, Ghosh D: Advances in fermentative biohydrogen production: the way forward? Trends Biotechnol 2009, 27:287-297.

3. Kraemer JT, Bagley DM: Improving the yield from fermentative hydrogen production. Biotechnol Lett 2007, 29:685-695.

4. Chou CJ, Jenney FE, Adams MWW, Kelly RM: Hydrogenesis in hyperthermophilic microorganisms: implications for biofuels. Metab Eng 2008, 10:394-404.

5. Kengen SWM, Goorissen HP, Verhaart M, Stams AJM, van Niel EWJ, Claassen PAM: Biological hydrogen production by anaerobic microorganisms. In Biofuels. Edited by: Soetaert W, Vandamme EJ. Chichester, UK: John Wiley 2009:197-221.

6. van Groenestijn JW, Hazewinkel JHO, Nienoord M, Bussmann PJT: Energy aspects of biological hydrogen production in high rate bioreactors operated in the thermophilic temperature range. Int J Hydrogen Energy 2002, 27:1141-1147.

7. Ljunggren M, Zacchi G: Techno-economic evaluation of a two-step biological process for hydrogen production. Biotechnol Prog 2010, 26:496-504.

8. de Vrije T, Bakker R, Budde MAW, Lai MH, Mars AE, Claassen PAM: Efficient hydrogen production from lignocellulosic energy crop Miscanthus by the extreme thermophilic bacteria Caldicellulosiruptor saccharolyticus and Thermotoga neapolitana. Biotechnol Biofuels 2009, 2:12.

9. van Niel EWJ, Budde MAW, de Haas GG, van der Wal FJ, Claassen PAM, Stams AJM: Distinctive properties of high hydrogen producing extreme thermophiles, Caldicellulosiruptor saccharolyticus and Thermotoga elfii. Int J Hydrogen Energy 2002, 27:1391-1398.

10. van der Werken HJG, Verhaart MRA, VanFossen AL, Willquist K, Lewis DL, Nichols JD, Goorissen HP, Mongodin EF, Nelson KE, van Niel EWJ, Stams AJM, Ward DE, de Vos WM, van der Oost J, Kelly RM, Kengen SWM: Hydrogenomics of the extremely thermophilic bacterium Caldicellulosiruptor saccharolyticus. Appl Environ Microbiol 2008, 74:6720-6729.

11. Ivanova G, Rakhely G, Kovacs KL: Hydrogen production from biopolymers by Caldicellulosiruptor saccharolyticus and stabilization of the system by immobilization. Int J Hydrogen Energy 2008, 33:6953-6961.

12. Kádár Z, de Vrije T, Budde MAW, Szengyel Z, Réczey K, Claassen PAM: Hydrogen production from paper sludge hydrolysate. Appl Biochem Biotechnol 2003, 105-108:557-566.

13. van Niel EWJ, Claassen PAM, Stams AJM: Substrate and product inhibition of hydrogen production by the extreme thermophile, Caldicellulosiruptor saccharolyticus. Biotechnol Bioeng 2003, 81:255-262.

14. Willquist $K$, Claassen PAM, van Niel EWJ: Evaluation of the influence of $\mathrm{CO}_{2}$ on hydrogen production by Caldicellulosiruptor saccharolyticus. Int J Hydrogen Energy 2009, 34:4718-4726.

15. Zeidan AA, van Niel EWJ: A quantitative analysis of hydrogen production efficiency of the extreme thermophile Caldicellulosiruptor owensensis $\mathrm{OL}^{\top}$. Int J Hydrogen Energy 2010, 35:1128-1137.

16. Soboh B, Linder D, Hedderich R: A multisubunit membrane-bound [NiFe] hydrogenase and an NADH-dependent Fe-only hydrogenase in the fermenting bacterium Thermoanaerobacter tengcongensis. Microbiology 2004, 150:2451-2463.

17. Schröder $C$, Selig $M$, Schönheit $P$ : Glucose fermentation to acetate, $\mathrm{CO}_{2}$ and $\mathrm{H}_{2}$ in the anaerobic hyperthermophilic eubacterium Thermotoga maritima: involvement of the Embden-Meyerhof pathway. Arch Microbiol 1994, 161:460-470.

18. Pauss A, Andre G, Perrier M, Guiot SR: Liquid-to-gas mass transfer in anaerobic processes: inevitable transfer limitations of methane and 
hydrogen in the biomethanation process. Appl Environ Microbiol 1990, 56:1636-1644.

19. Kraemer JT, Bagley DM: Supersaturation of dissolved $\mathrm{H}_{2}$ and $\mathrm{CO}_{2}$ during fermentative hydrogen production with $\mathrm{N}_{2}$ sparging. Biotechnol Lett 2006, 28:1485-1491.

20. Kraemer JT, Bagley DM: Optimisation and design of nitrogen-sparged fermentative hydrogen production. Int J Hydrogen Energy 2008, 33:6558-6565.

21. de Vrije T, Mars AE, Budde MAW, Lai MH, Dijkema C, de Waard P, Claassen PAM: Glycolytic pathway and hydrogen yield studies of the extreme thermophile Caldicellulosiruptor saccharolyticus. Appl Microbiol Biotechnol 2007, 74:1358-1367.

22. Han K, Levenspiel O: Extended Monod kinetics for substrate, product, and cell inhibition. Biotechnol Bioeng 1988, 32:430-437.

23. Willquist $\mathrm{K}$, van Niel EWJ: Lactate formation in Caldicellulosiruptor saccharolyticus is regulated by the energy carriers pyrophosphate and ATP. Metab Eng 2010, 12:282-290.

24. Luedeking R, Piret EL: A kinetic study of the lactic acid fermentation. $J$ Biochem Microbiol Technol Eng 1959, 1:393-412.

25. Willquist K: Physiology of Caldicellulosiruptor saccharolyticus: a hydrogen cell factory. PhD thesis Lund University, Department of Applied Microbiology; 2010.

26. Hill GA: Measurement of overall volumetric mass transfer coefficients for carbon dioxide in a well-mixed reactor using a pH probe. Ind Eng Chem Res 2006, 45:5796-5800.

27. Linton KJ, Higgins CF: Structure and function of $A B C$ transporters: the ATP switch provides flexible control. Pflügers Arch Eur J Physiol 2007, 453:555-567.

28. Chevance FF, Erhardt M, Lengsfeld C, Lee SJ, Boos W: Mlc of Thermus thermophilus: a glucose-specific regulator for a glucose/mannose $A B C$ transporter in the absence of the phosphotransferase system. J Bacteriol 2006, 188:6561-6571.

29. Nielsen JH, Villadsen J, Lidén G: Bioreaction Engineering Principles. 2 edition. New York: Kluwer Academic/Plenum Publishers; 2003.

30. Koch AL: Diffussion: the crucial process in many aspects of the biology of bacteria. Adv Microb Ecol 1990, 2:37-70

31. Thauer RK, Jungermann K, Decker K: Energy conservation in chemotrophic anaerobic bacteria. Bacteriol Rev 1977, 41:100-180.

32. Zeidan AA, van Niel EWJ: Developing a thermophilic hydrogen-producing co-culture for efficient utilization of mixed sugars. Int I Hydrogen Energy 2009, 34:4524-4528.

33. Koskinen PEP, Lay C, Puhakka JA, Lin P, Wu S, Örlygsson J, Lin CY: Highefficiency hydrogen production by an anaerobic thermophilic culture from an Icelandic hot spring. Biotechnol Bioeng 2008, 101:665-678.

34. Hussy I, Hawkes FR, Dinsdale R, Hawkes DL: Continuous fermentative hydrogen production from a wheat starch co-product by mixed microflora. Biotechnol Bioeng 2003, 84:619-626.

35. Mizuno O, Dinsdale R, Hawkes FR, Hawkes DL, Noike T: Enhancement of hydrogen production from glucose by nitrogen gas sparging. Bioresour Technol 2000, 73:59-65.

36. Kyazze G, Martinez-Perez N, Dinsdale R, Premier GC, Hawkes FR, Guwy AJ, Hawkes DL: Influence of substrate concentration on the stability and yield of continuous biohydrogen production. Biotechnol Bioeng 2006, 93:971-979. evaluation of the effect of hydrogen and osmolarity on hydrogen production by Caldicellulosiruptor saccharolyticus. Biotechnology for Biofuels 2011 4:31.

\section{Submit your next manuscript to BioMed Central and take full advantage of:}

- Convenient online submission

- Thorough peer review

- No space constraints or color figure charges

- Immediate publication on acceptance

- Inclusion in PubMed, CAS, Scopus and Google Scholar

- Research which is freely available for redistribution

Submit your manuscript at www.biomedcentral.com/submit 